\title{
A Physiological Study of the Germination of Helianthus annuus.
}

\author{
BY \\ EDWIN C. MILLER. \\ With twenty-four Figures in the Text. \\ Historical SKetch.
}

T 1842 De Saussure (1) carried on the first investigations in regard to the 1 chemical changes which take place in oily seeds during their germination. He undertook this work in order to test the suggestion of Raspail that the oil in seeds might subserve the same purpose during germination as the starch in the cereal grains. De Saussure investigated the seed and seedlings of the hemp, rape, and madia, and obtained the results shown in the table below :-

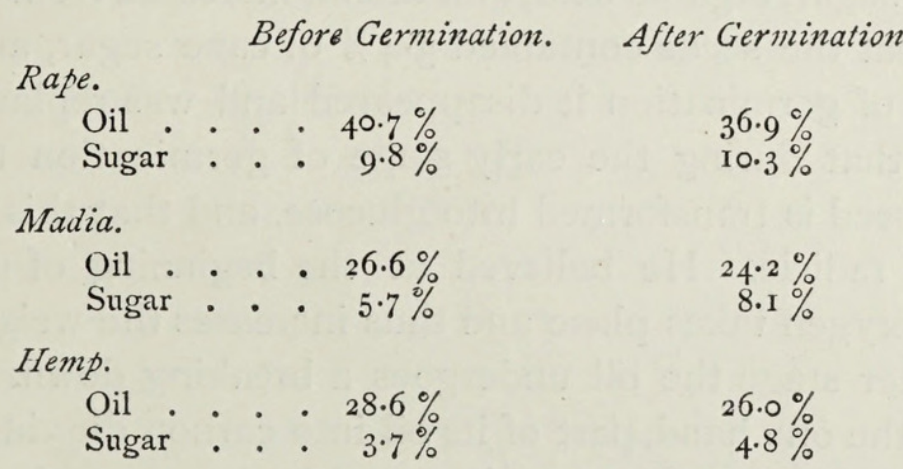

During his experiments with these seeds, De Saussure investigated for the first time the respiration of oily seeds during the early period of their germination. He found that the amount of oxygen absorbed by them in a given time was greater than the volume of $\mathrm{CO}_{2}$ produced. A portion of rapeseed for instance had absorbed, up to the period when their hypocotyls had reached a length of II mm., $3^{\mathrm{I} \cdot 4}$ c.c. of oxygen, and had produced only 24.39 c.c. of carbon dioxide. He observed this same phenomenon in the other oily seeds with which he experimented.

As a result of these experiments he announced two important conclusions: (I) That during germination the seedlings of oily seeds generate sugar, and that they destroy, in part at least, the oil contained in them; and (2) that

[Annals of Botany, Vol. XXIV. No. XCVI. October, 1910.] 
oily seeds differ from those which contain starch in that they absorb during germination a larger volume of oxygen than they produce carbon dioxide.

Letellier (2), while working in the laboratory of Boussingault, found that the oil contained in oily seeds diminished as the germination progressed. His data for the seeds and seedlings of rape and madia are as follows :-

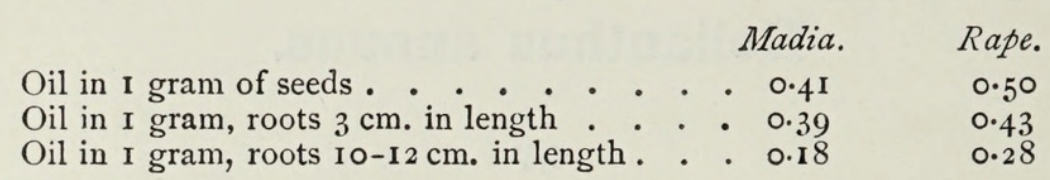

From the work of these two investigators it was thus definitely established that the oil in seeds is a storage product and subserves the same purpose as the reserve carbohydrates, although the chemical processes in the utilization of these classes of substances are different.

Hellriegel (3) in 1855 made the most extensive and thorough investigations on the germination of oily seeds up to his time. He worked only with the seedlings of the rape, but examined his material at five different stages and thus obtained an idea of the changes which take place from the beginning of germination to the time when the seedling had cast off the seed-coat. He found that at first the seedlings increased in weight, but in a short time there was a gradual decrease. He found that the oil decreased from $47 \%$ in the seed to $36 \%$ in the oldest seedlings, and at the same time the sum of the sugar, organic acid, and tannin increased from $7 \cdot 7 \%$ to $15.4 \%$. He observed that the seeds contained $3.4 \%$ of cane sugar, and that during the early stage of germination it disappeared and was replaced by glucose. He concluded that during the early stage of germination the cane sugar present in the seed is transformed into glucose, and that this is used at once by the young radicle. He believed at the beginning of germination an absorption of oxygen takes place and thus increases the weight of the seedling. At a later stage the oil undergoes a breaking down. The seedling transforms, on the one hand, part of its oil into carbon dioxide and water by the oxidation of the constituent carbon and hydrogen, and obtains thereby the necessary energy for its growth; on the other hand, it takes up a further quantity of oxygen which is incorporated into its residual constituents. These two processes combine to produce some compound which is rich in oxygen and from which by further splitting glucose is formed.

Sachs $(4,5)$ in 1859 and in 1863 made a very detailed study of the products of oily reserves during germination. He investigated in a microchemical way the seeds and seedlings of Ricinus communis, Helianthus annuns, Cucurbita Pepo, Amygdalus communis, Allium Cepa, and numerous others. Sachs concluded from the investigations that the oil in seeds was transformed during germination wholly or partly into starch. According to his view, in some seedlings all of the oil was transformed into starch, while in others only part of the oil was changed into starch and the 
remainder was converted directly into sugar. He held that the starch could not be a transition between the oil and sugar because the oil in many seedlings is transformed directly into sugar, while starch appears only in the starch sheath. On the other hand, he argued against the idea that the oil was first changed to sugar and then to starch, because starch often appears in the germination in many places in the seedling where sugar is not present before or at the time of its appearance there.

Peters (6) in I86 I, by analyses of the seedlings of Cucurbita Pepo, found that during germination the amount of oil decreased from $49.5 \%$ of the dry material to $12.7 \%$ when the seedlings were well developed, and that during this period there was an increase in the amount of carbohydrate, especially starch.

Fleury (7) in 1865 , in a series of investigations carried out on the seedlings of the castor-oil bean, sweet almond, rape, and spurge, observed again the fact that as the amount of oil decreased, there was an increase in the amount of sugar. He also observed the fact that the amount of oxygen in early stages of the seedlings was greater than the amount in the resting seeds. He observed that some of the oil had become volatile, and that one or more non-volatile acids had made their appearance. He concluded that during the germination an oxidation of the oil takes place with the forma tion of sugar. He suggests that this might be due to some catalytic agent.

In 187 I Müntz (8), in a study of the seeds of rape, poppy, and radish, observed for the first time that during germination the oil in the seeds gives rise to free fatty acid. He found that the amount of free fatty acid in the oil increased from $10 \%$ in the resting seed to as high as $98 \%$ in the ten-day seedling. He concluded that during the germination the oil is split up into free fatty acid and glycerine, and that the glycerine at once disappears, since he was not able to detect it at all. He also observed that the free fatty acid during the time of germination undergoes a slow but progressive absorption of oxygen not exceeding $3 \%$ to $4 \%$ of its weight.

Laskovsky (9) (1874) worked with the seeds of the squash and verified the earlier work of Peters. He observed, as did his predecessors, that as the content of oil diminished the amount of cellulose, starch, and sugar increased, and thought that it was probable that the carbohydrates were formed at the expense of the oil which disappeared.

Detmer $(10,11)$ in 1875 found in the study of the hemp seed that in seven-day seedlings the oil content had decreased from $33 \%$ to $17 \%$. During that period starch had made its appearance and amounted to $8.9 \%$. In ten-day seedlings the amount of oil had fallen to $15 \%$, and the starch to $4.6 \%$. Since no sugar was detected, he concluded that the starch is the direct product of the oil. In his work in 1880 , in discussing the work of Müntz, he suggested that the glycerine formed is changed at once into unknown bodies, and that the free fatty acid might be the source of the 
starch formed. He gave the following formula to indicate a possible origin of starch from oleic acid :-

$$
\mathrm{C}_{18} \mathrm{H}_{34} \mathrm{O}_{2}+27 \mathrm{O}=2\left(\mathrm{C}_{6} \mathrm{H}_{10} \mathrm{O}_{5}\right)+6 \mathrm{CO}_{2}+7 \mathrm{H}_{2} \mathrm{O} \text {. }
$$

In 1890 Green (12) carried on a detailed study of the changes which take place in the reserve products of Ricinus communis during germination. He discovered the enzyme lipase, and showed that the glycerides were split into free fatty acid and glycerine by its action. Green thought that the glycerine thus formed gives rise directly to sugar, and that the free fatty acid gives rise to a crystalline vegetable acid soluble in water, but which he was unable to identify. He concluded that the starch formed in the embryo and young plant is a direct product of the sugar formed from the glycerine, and not a direct product of the oil as Sachs suggested.

In $189 \mathrm{I}$ Schmidt (13) published the results of the most extensive experiments that have ever been carried out on the transportation of the oily reserves in seedlings. He concluded that in many seedlings the oil as such is transported to the different parts, and that only after it has reached its destination is it broken up into the necessary products for the growth of the seedlings. His conclusions were based upon the fact that in seedlings in which oil transportation seems to take place, the amount of free fatty acid present in the place of the storage of the oil is small, and further, that in many parts of the plant remote from the cotyledons considerable quantities of neutral oil appear. He found that the cellulose walls of plant-cells are permeable to oil which contains free fatty acid, and that the greater the amount of acid the more readily permeable are the cell-walls. According to his view the free fatty acid unites with some substance in the cell-wall to form a soap which not only holds a capillary attraction for the oil, but in part emulsifies it and in that manner passes it through the cellwalls.

Schmidt observed also a decrease in value of the iodine number in the unsaturated oils and fatty acids during the progress of germination.

In 1893 Leclerc du Sablon (14) in a note states that he found a decrease in the amount of oil in the endosperm of Ricinus communis from $69 \%$ in the resting seed to II \% when the seedlings had reached a length of $\mathrm{I} 2 \mathrm{~cm}$. Since during that time the reducing sugar increased from $0.4 \%$ to $14 \%$, he concluded that probably the oil was transformed into glucose.

The same author (15) in the following year worked with the seedlings of the hemp. The seeds contain about $3 \%$ of cane sugar as a reserve. At the beginning of germination this decreases and glucose appears. During the progress of germination the amount of saccharose increased, and when the radicles had attained a length of $5 \mathrm{~cm}$. it amounted to $12 \%$ of the dry material. The glucose in this time had increased to only $5 \%$. Leclerc du Sablon concluded from this that saccharose is the first product of the oil. The glucose is derived from the saccharose by a process of hydrolysis. 
Frankfurt (16) (I894) examined the seed and seedlings of the hemp and the sunflower. In his work on the hemp seedlings he confined himself to the proteid and its products.

In his work on the sunflower he examined the seeds and the seedlings at the age of four weeks. He identified both asparagin and glutamin in the hypocotyls and the roots, but only asparagin in the cotyledons. In the seedlings he was able to identify malic acid. He identified the reducing sugar in the seedling as glucose, and the non-reducing sugar as saccharose.

In 1895 Leclerc du Sablon (17) made extensive analyses of the seedlings of the castor-oil bean, rape, hemp, poppy, and several others. He found in all the seedlings examined practically the same results as in his preliminary work. He found that the amount of free fatty acid as well as the sugar content increased during the progress of germination, while the oily reserve diminished. He was unable to detect glycerine at any time during the germination. He concluded then that an enzyme might be present in the seedling which can liberate the fatty acid in such a way that glycerine is not set free. He believes that the process of the liberation of the acid is a more complex one than simple saponification.

Leclerc du Sablon thought that the glycerine with the acid still combined with it goes directly to form the carbohydrate, while the free fatty acid may be a transitory decomposition product which will give rise to other products capable of being assimilated. He believed that the first carbohydrate formed was either saccharose or a sugar very nearly related to it. In some cases he believed that dextrins appear as transition products between the oil and the sugar formed.

Wallerstein (18) $(1896)$ in his investigations of malt found that the amount of oil diminished with the age of green malt. At the same time the value of the iodine number fell, and the acid value of the oil increased.

Merlis (19) (1897) observed in the germination of Lupinus angustifolius that the oily content of $7 \cdot 4 \%$ in the seeds diminished to $\mathrm{I} \cdot 6 \%$ in the fifteenday seedlings, while the cellulose increased from $\mathrm{r} \cdot 5 \%$ to $8 \cdot 4 \%$.

Leclerc du Sablon (20, 21) (1897) investigated the seedlings of the sweet and bitter almonds and of the black walnut in the same manner that he had previously studied the oily seeds, and obtained results substantially the same as those from his former work. In the walnut he also investigated the changes which occur during the formation of the oil as a reserve product. He found that the acid value of the oil when it first begins to appear is greater than when the seed is nearing maturity. In the earlier stages of the formation of the seed, reducing sugar was present to the amount of $7.6 \%$, but decreased in amount as the oil appeared, and finally could not be detected. The processes of building up the oil for a reserve product seem to be just the opposite from those taking place during germination.

An attempt was made by Hanriot (22) (1898) to isolate and identify the 
products produced by the artificial oxidation of oil. He succeeded in getting oil to absorb $15 \%$ of its weight in oxygen. In the product thus obtained he could detect neither tannic nor oxalic acid, but acetic acid and butyric acid were identified. The product obtained gave none of the reactions of starch, cellulose, or sugar.

The germination of Arachis hypogaea and Ricinus communis was extensively studied by Maquenne (23) in I898. He selected these two seedlings in order to make a special study of the behaviour of saturated and unsaturated oils during germination. Arachic acid is a saturated compound with the formula $\mathrm{C}_{20} \mathrm{H}_{40} \mathrm{O}_{2}$, while ricinoleic acid is unsaturated and has the formula $\mathrm{C}_{18} \mathrm{H}_{34} \mathrm{O}_{3}$.

Maquenne found in Arachis that the cellulose and sugar content at its maximum amount in the seedling had increased $5.6 \%$ of the weight of the dry material. In the seedlings of Ricimus, on the other hand, these constituents had at their maximum increased $16 \%$ of the dry weight. The amount of carbohydrate which the glycerine of the oil could furnish for Ioo parts of the dry material would be about $5 \%$. The amount of carbohydrate obtained in the case of Arachis is approximately that amount, while in Ricinus it is much higher. From this Maquenne concluded that only the glycerine or the saturated oils contribute to the formation of sugar, and that their fatty acids serve only for oxidation. The fatty acids of the unsaturated oils, on the other hand, contribute to the formation of sugar. The production of carbohydrate from an unsaturated fatty acid is due to the presence of the allyl group in its molecule. These groups, rendered free by the oxidation of the two ends of the chain, transform themselves into glycerine, and then by polymerization form the carbohydrates.

Sani (24) in 1900 observed in seedlings of the olive one week old a decrease of the oily content from $42 \%$ to $6 \cdot 2 \%$.

Mazé (25) (I900) by the autolysis of the macerated seedlings of Ricinus communis obtained an increase in the amount of reducing sugar. After a period of twenty-two hours at a temperature of $53^{\circ} \mathrm{C}$. he obtained an increase of $2.6 \%$ reducing sugar. The maximum increase of sugar found was $3.5 \%$ of the material used or $7 \%$ of the oily content. Since the controls during the same time showed no increase of sugar content, Mazé concluded that in the seedling of this plant an enzyme is present which has the power to transform oil into sugar.

Kirkwood and Gies (27) (1902), in a chemical study of the coco-nut, found evidence of the appearance of carbohydrate at the expense of the oil.

Jegorow (27) (1904) investigated the seedlings of Cucurbita maxima, which were taken at periods of $6,10,20$, and 28 days. He found that at the end of the first period the quantity of oil had increased from $45 \%$ to $47 \%$, and that the total weight of the dry matter had also increased. During the rest of the period there was a gradual decrease of the oily reserve. The 
value of the iodine number of the oil decreased from II 3.5 to 105. The acid value of the oil increased from less than I \% to $56 \%$. A considerable part of the acid was volatile. The cellulose and sugar content during the progress of germination each showed an increase of nearly $10 \%$.

Von Fürth (28) (1904) examined the oil of Helianthus anmus and Ricinus communis before germination, and after the radicle of the seedlings had attained a length of 4 to $5 \mathrm{~cm}$. He found that the acetyl value of the oil of Helianthus during the period decreased from 87.5 to 50.5 , while there was little change in the iodine number. The mean molecular weight of the fatty acid during the period did not change materially. From these results, Fürth concluded that the normal fatty acid does not change into oxy-fatty acid, and that there is no ground for assuming that the unsaturated acid becomes saturated during germination. Since the mean molecular weight of the acid does not change, there is no proof that the fatty acids are broken down into the lower carbon groups. Fürth was unable to detect the vegetable acid mentioned by Green in his experiments with Ricinus communis.

In 1905 Green (29) continued his investigation of the germination of Ricinus. He found that the amount of lecithin decreased in the early stages of the seedlings, but subsequently a gradual increase of this compound took place. He thought it probable that the oily reserve furnished glycerine and acid groups for this compound. He identified the non-reducing sugar present as saccharose, and the reducing sugar as invert sugar. He concluded that his previous opinion that the sugar present during germination is derived from glycerine is erroneous. The organic acid was again investigated, but its identity was not established. He considers that it is derived from the oil by oxidation, but that it has no connexion either directly or indirectly with the formation of carbohydrate.

\section{EXPERIMENTAL INVESTIGATIONS.}

CULTURE METHODS.

The sunflower seeds used in this work were of the variety known as the 'Large Russian', and were purchased from a local seedsman in the spring of 1909. The quantity of seeds purchased at that time was sufficient in amount to furnish all the material needed in this investigation.

The seedlings for these experiments were grown in white quartz sand. This sand was washed first with hot and then with cold water before being transferred to the boxes or pots in which the seedlings were grown. The seeds were planted in the sand at a depth of about one half-inch, and were watered with the ordinary city water. ${ }^{1}$ The vessels containing the seeds

1 The total amount of solids in the New Haven city water is very low, only $65-75$ milligrams to the litre. 
were placed in the greenhouse, where the temperature was kept between $65^{\circ}$ and $75^{\circ} \mathrm{F}$.

Most of the investigations on the germination of oily seeds have been limited to the early stages of the seedlings before they have reached the surface of the ground. The few investigations that have been made on plants of this kind at a more advanced stage have been made on seedlings which have been grown in darkness. As it is a well-known fact that plants which are grown in darkness are abnormal, chemically as well as morphologically, one should be careful in accepting the results obtained under such conditions as indicating the processes which take place in the seedling under normal conditions.

Since it was thought advisable to examine the seedlings of the sunflower at several stages after they had reached the surface of the soil, a method was sought whereby the seedlings could have the normal tonic

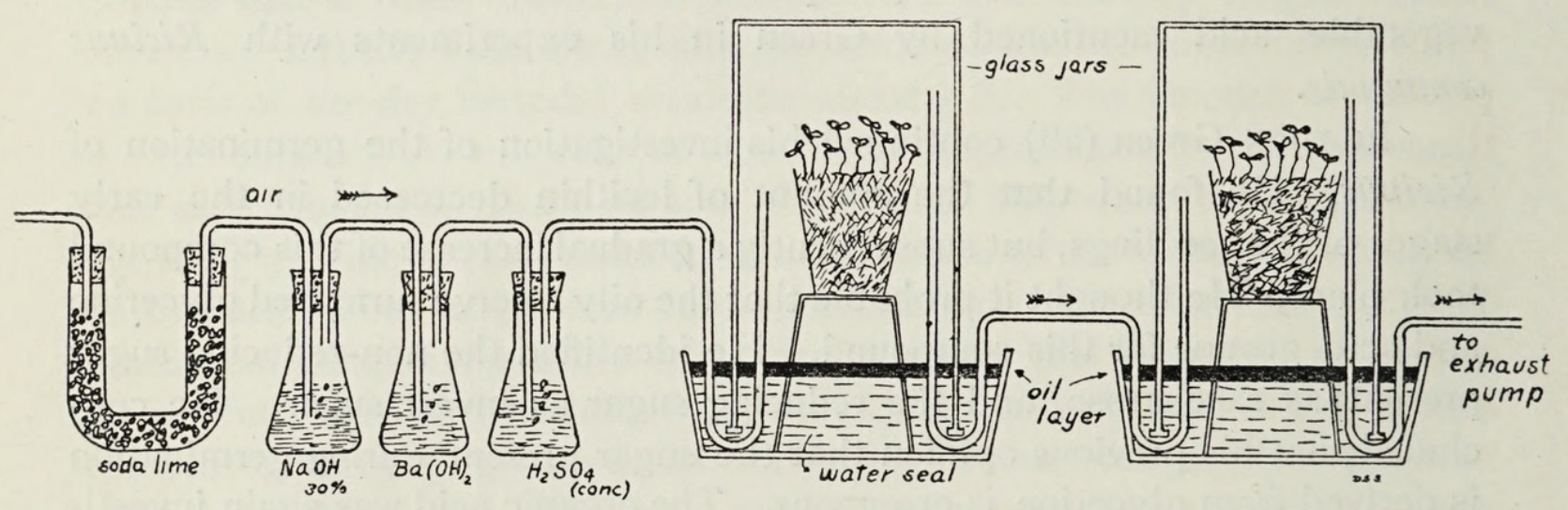

FIG. I. Apparatus for growing plants in the absence of carbon dioxide.

influence of the sunlight and at the same time be unable to carry on the processes of photosynthesis. For these advanced stages, the seeds were planted in the sand in flower-pots or pans which had been coated on the inside with a layer of paraffin. After the seedlings had reached the surface of the sand, the pans and pots containing them were placed in the apparatus as shown in Fig. I.

This apparatus consisted of twelve large glass jars, placed in large tin pans and connected with each other by means of glass tubing. The jars were sealed with water and the water then covered with a layer of engine oil about $\frac{3}{4} \mathrm{~cm}$. in thickness. This layer of oil retarded the evaporation of the water into the jars above, and thus prevented abnormal conditions which might arise from an excess of moisture. At intervals in the connexions between the jars, wash-bottles containing strong sulphuric acid were inserted in order to take up the moisture in the air due to the transpiration of the seedlings, and the evaporation from the sand. The series of jars was connected at one end to a filter pump, and a stream of air continually pulled through the apparatus while the seedlings were contained in 
it. The air before its entrance into the apparatus first passed through a soda-lime tube, then through a wash-bottle containing $30 \%$ sodium hydroxide, then through baryta water, and finally through concentrated sulphuric acid. That the baryta water showed no signs of turbidity was a sufficient indication that the air entering the apparatus was entirely free from carbon dioxide. To avoid the increased pressure due to condensation of the moisture in the bends of the glass tubes connecting the jars, the apparatus was taken apart once or twice during the growth of the advanced stages and the tubes dried. This was always done at night and the apparatus again set to work, so that by daylight the air in the apparatus was free from carbon dioxide. This method of growing the seedlings has the advantage not only of preventing photosynthesis and absorption, but at the same time it supplies the plant with oxygen and provides it with the normal light conditions. The carbon dioxide liberated by the seedling by respiration during the daylight is, under these conditions, probably used in photosynthetic processes before it leaves the plant. There seems to be no possible means of preventing the $\mathrm{CO}_{2}$ thus liberated from being utilized by the plant in daylight.

In many of the experiments carried out on seedlings the analyses have been made upon material obtained by grinding up the whole seedling. Without making separate analyses of the hypocotyls and cotyledons in a seedling of the type of the sunflower, it would be impossible to obtain a correct insight into the metabolic changes taking place in the reserve material and the manner of their transportation from place to place. In this work separate analyses were made of the hypocotyls and cotyledons. The seedlings were taken at the different stages, and after carefully washing them to free the sand, the hypocotyls were separated from the cotyledons by means of a razor. The two parts were then ground up separately and dried according to the process described below. In preparing the seeds for analysis the hulls were removed and the tip or rudimentary hypocotyl and root were removed from the cotyledons. The tips and cotyledons were dried down separately in the same manner as below mentioned.

\section{STAGES EXAMINED.}

Seeds. The seeds of Helianthus anmuns contain as a reserve material between 50 and $56 \%$ of ether extract and about $25 \%$ of proteid matter. The oil, according to Thorp, ${ }^{1}$ consists of the glycerides of oleic, palmitic, arachidic, and linoleic acids. The amount of free acid present in the ether extract in the seeds used in this work amounted to less than one per cent. There is also a non-reducing sugar present to the amount of nearly $4 \%$. This has been identified by Frankfurt ${ }^{2}$ as saccharose. No starch is present, and only a trace of reducing sugar.

1 Thorp, Outlines of Industrial Chemistry, p. 326.

$21 . c$. 
The proteid is present in the form of granules or grains, and according to Osborne and Campbell (30) consists principally of the globulin edestin.

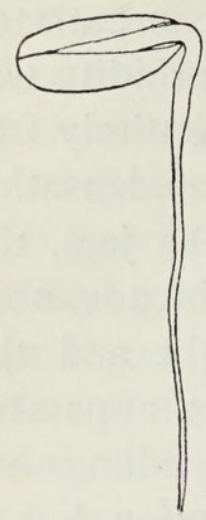

FIG. 2. Stage I of Seedlings.

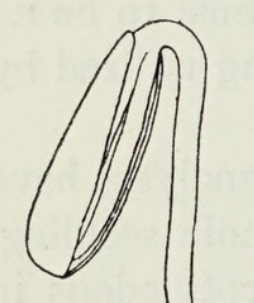

(

All the cells of the seed, including the rudimentary root and hypocotyl, are closely packed with reserve material.

Stage $I$. At this stage the hypocotyls and roots of the seedlings have reached a length of from 2.5 to $3.5 \mathrm{~cm}$., and have the appearance shown in Fig. 2. The reserve material at the beginning of germination first disappears from the stretching tip. The disintegration and disappearance of material then take place in the lower end of the cotyledon. At this stage the reserve material has disappeared, for the most part, from the hypocotyls and roots, and the proteid grains have broken up in the lower third of the cotyledons. The proteid matter in the upper two-thirds of the cotyledons is apparently yet intact. Starch can now be detected in the starch sheath of the hypocotyl. The root tip is now active as a growing point, and the root is increasing in length in the usual way.

Stage II. The hypocotyls and roots have now reached a length of 7.5 to $\mathrm{II} \cdot 5 \mathrm{~cm}$. The seedlings were just breaking the ground and the cotyledons were not yet separated from the seed-coats. The cotyledons as yet were only yellowish in colour. The time required for the seedlings to reach this stage was from $4 \frac{1}{2}$ to 5 days. The proteid material at this period has disintegrated into small granules in all the cells of the cotyledons. It has almost all disappeared from the lower part of the cotyledons, and the cells in that region are beginning to form vacuoles. The starch sheath is filled with starch as in the preceding stage, and starch also makes its appearance in the parenchyma of the mid veins in the lower part of the cotyledons. See Fig. 3.

Stage III. The time required for the seedling to reach this stage was about seven days. As soon as the plants had appeared above the surface of the ground the pots and pans containing them were transferred to the apparatus free from $\mathrm{CO}_{2}$ and kept there until they had made the desired growth. The seedlings in this stage were kept in the $\mathrm{CO}_{2}$-free apparatus one day. At this stage the cotyledons had become a bright green and were spread out perpendicular to the hypocotyl.

FIG. 3. Stage The hypocotyls had now reached a length of 5 to $6.5 \mathrm{~cm}$. above the ground. The root had reached the same length, while the side roots had attained a length of from 2.5 to $3.5 \mathrm{~cm}$. See Fig. 4. The plumule had as yet not developed. The cells of the starch 
sheath are yet filled with starch and it appears in the parenchyma of the veins for the greater part of their length in the cotyledons.

The greater part of the proteid matter had now disappeared from the cells and most of them were beginning to form vacuoles.

Stage $I V$. The time required for the seedlings to reach this stage was about ten days. Six days were required for them to reach the surface

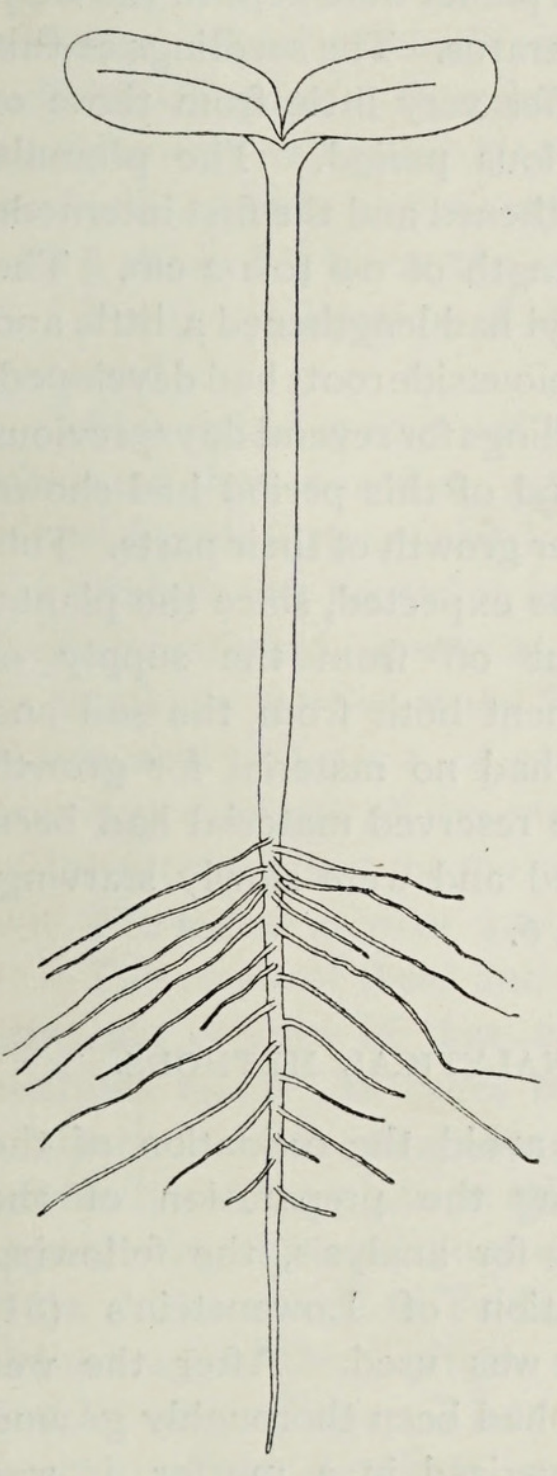

FIG. 4. Stage III of Seedlings.

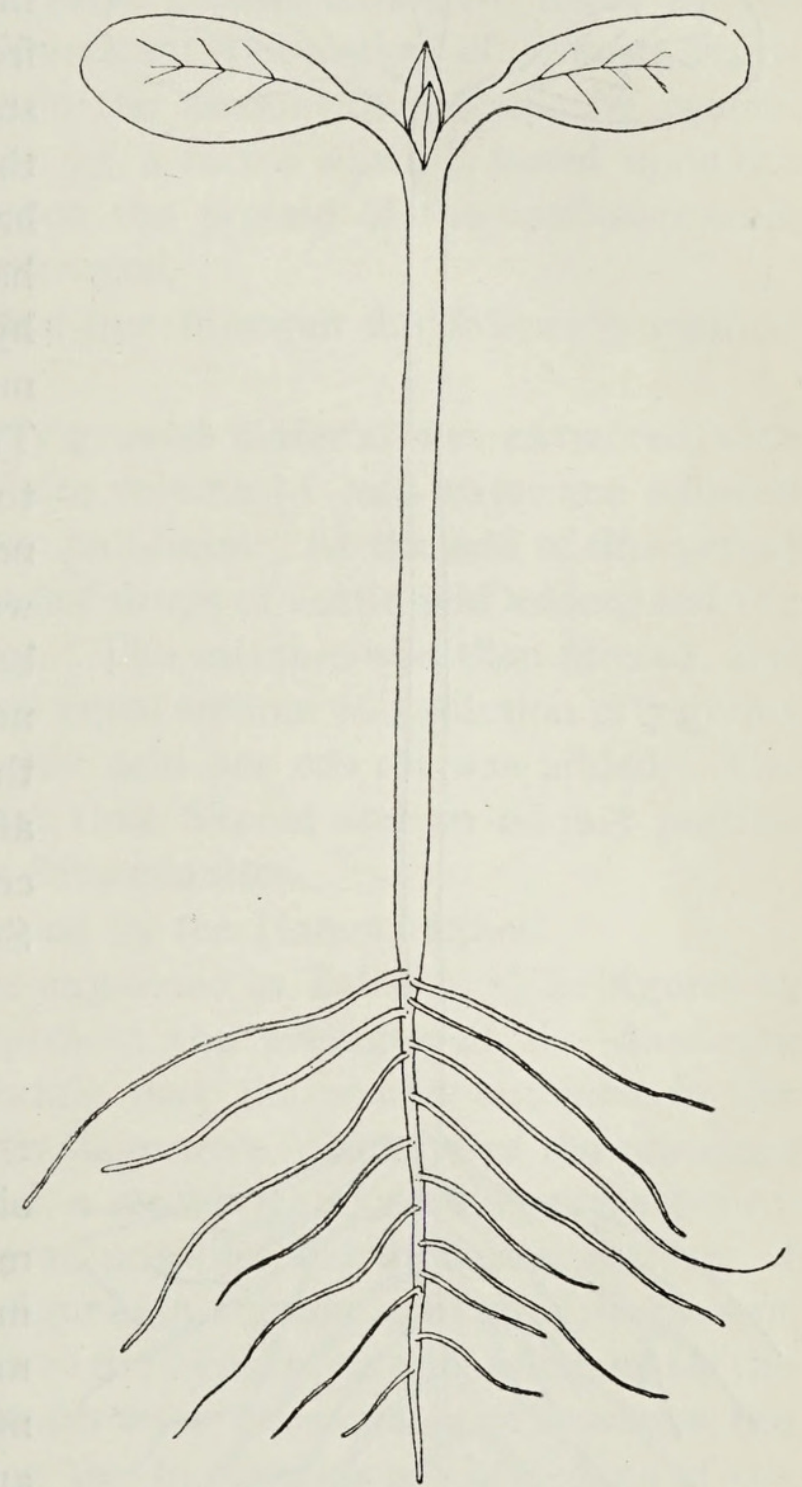

FIG. 5. Stage IV of Seedlings.

of the ground, after which they were placed in the $\mathrm{CO}_{2}$-free apparatus and left four days. The cotyledons had broadened and lengthened by this time and the plumule had become two-leaved. See Fig. 5. The hypocotyl had a length of from 8.5 to $10 \mathrm{~cm}$. from the ground to the cotyledons. The main roots had a length of from 6 to $7.5 \mathrm{~cm}$. and had developed a copious growth of side roots. The starch still remained in the places mentioned in the previous stages, but in a much smaller quantity. The 
cells of the cotyledons were now apparently free from all reserve material. They had enlarged and had the appearance of the parenchyma cells of an ordinary vegetative leaf. At this stage the plant has evidently become wholly independent.

Stage $V$. The age of the seedlings used at this stage was thirteen

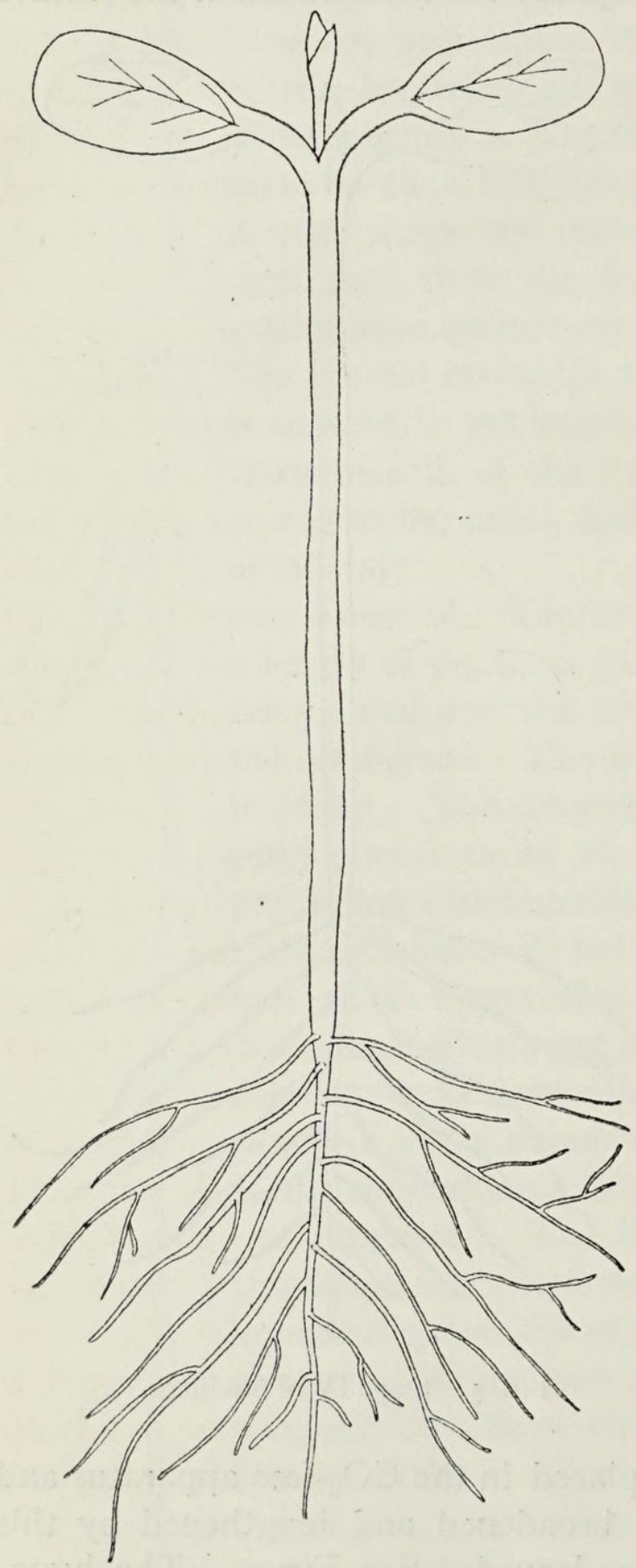

FIG. 6. Stage V of Seedlings. days, and during the last seven of these the plants were kept in the $\mathrm{CO}_{2}-$ free apparatus. The seedlings at this stage differ very little from those of the previous period. The plumule had lengthened and the first internode had a length of 0.6 to $\mathrm{I} \cdot 2 \mathrm{~cm}$. The hypocotyl had lengthened a little and more copious side roots had developed. The seedlings for several days previous to the end of this period had shown no further growth of their parts. This was to be expected, since the plants, being cut off from the supply of nourishment both from the soil and the air, had no material for growth after the reserved material had been consumed and were slowly starving. See Fig. 6.

\section{ANALYTICAL METHODS.}

To avoid the oxidation of the oil during the preparation of the material for analysis, the following modification of Lowenstein's (31) method was used. After the wet material had been thoroughly ground and pulverized in a mortar, it was transferred to broad, shallow pans on the water-bath and treated with twice its volume of $95 \%$ alcohol. After the alcohol had evaporated the process was repeated a second and a third time and again with absolute alcohol.

After the evaporation of the alcohol the material was placed in the oven at $100^{\circ}-105^{\circ} \mathrm{C}$. for 20 to 30 minutes and then transferred to the desiccator and finally to tightly closed vessels until needed for analysis. 
The material obtained in this manner was not oxidized in the least and was a white or yellow powder.

Upon the material thus prepared duplicate analyses were made for the following constitutents: ash, moisture, ether extract, total sugar, reducing sugar, cellulose, total nitrogen, and proteid-free nitrogen. The amount of free fatty acid and the iodine number are determined for the ether extract.

The determinations of most of these constituents were made by the ordinary official methods of the American Association of Official Agricultural Chemists. In order to obtain the amount of protein, the protein nitrogen was multiplied by the factor 5.5 , a factor which is based upon the work of Osborne and Campbell ${ }^{1}$ upon the proteid of the sunflower seed, which showed it to contain I $8 \%$ of nitrogen.

For the estimation of the proteid-free nitrogen the following method was used :-

A weighed portion of the finely ground material was extracted with ether and then stirred up with a definite volume of cold water and allowed to stand with frequent stirring for one half-hour. At the end of this period the mixture was heated to boiling, a few drops of acetic acid added, and the boiling continued for several minutes. The mixture was then filtered, and to an aliquot portion of the filtrate an equal volume of a solution of 7 grams tannic acid and 2 c.c. of glacial acetic acid per 100 c.c. was added. The tannin precipitate of the protein was then filtered and an aliquot portion of the filtrate taken for the nitrogen determination.

The iodine number was determined by the Hanus method.

The result of these analyses are expressed in Table I. The figures in any one column of that table represent the averages of the duplicate analyses made. In order to be certain that the results obtained in the analyses of the seedlings at any given stage were indicative of the processes normally taking place at that period, a second lot of seedlings was grown, reproducing the conditions as nearly as possible, and duplicate analyses of these made. Thus in Table I the figures in column $a$, Stage I, represent the average of the duplicate analyses on the hypocotyls or cotyledons for the first lot of seedlings. The figures under $b$ for the same stage represent the average of the duplicate analyses on the hypocotyls or cotyledons of the second lot of seedlings grown. In Stages I and II a third lot was grown and analysed for certain constituents as shown. Two series of duplicate analyses were made on the cotyledons of the seeds as shown in the table, thus ensuring against possible error in sampling.

It is seen that the results obtained from the two lots of seedlings of any one stage correspond as closely as could be expected. It was found that under approximately like conditions, the time required for the different lots of seedlings to reach the desired stage varied only a few hours. 


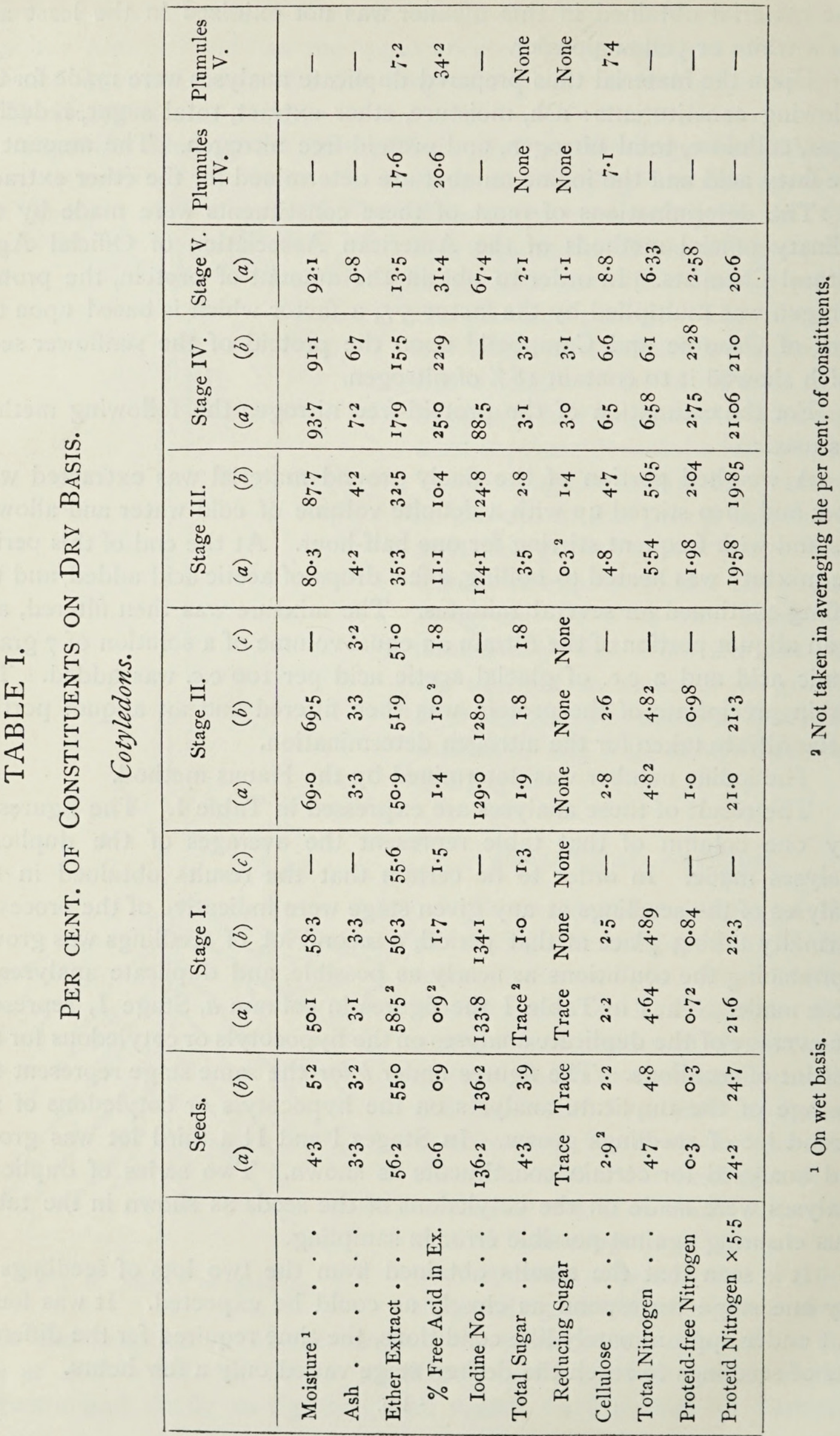


Germination of Helianthus annuus.

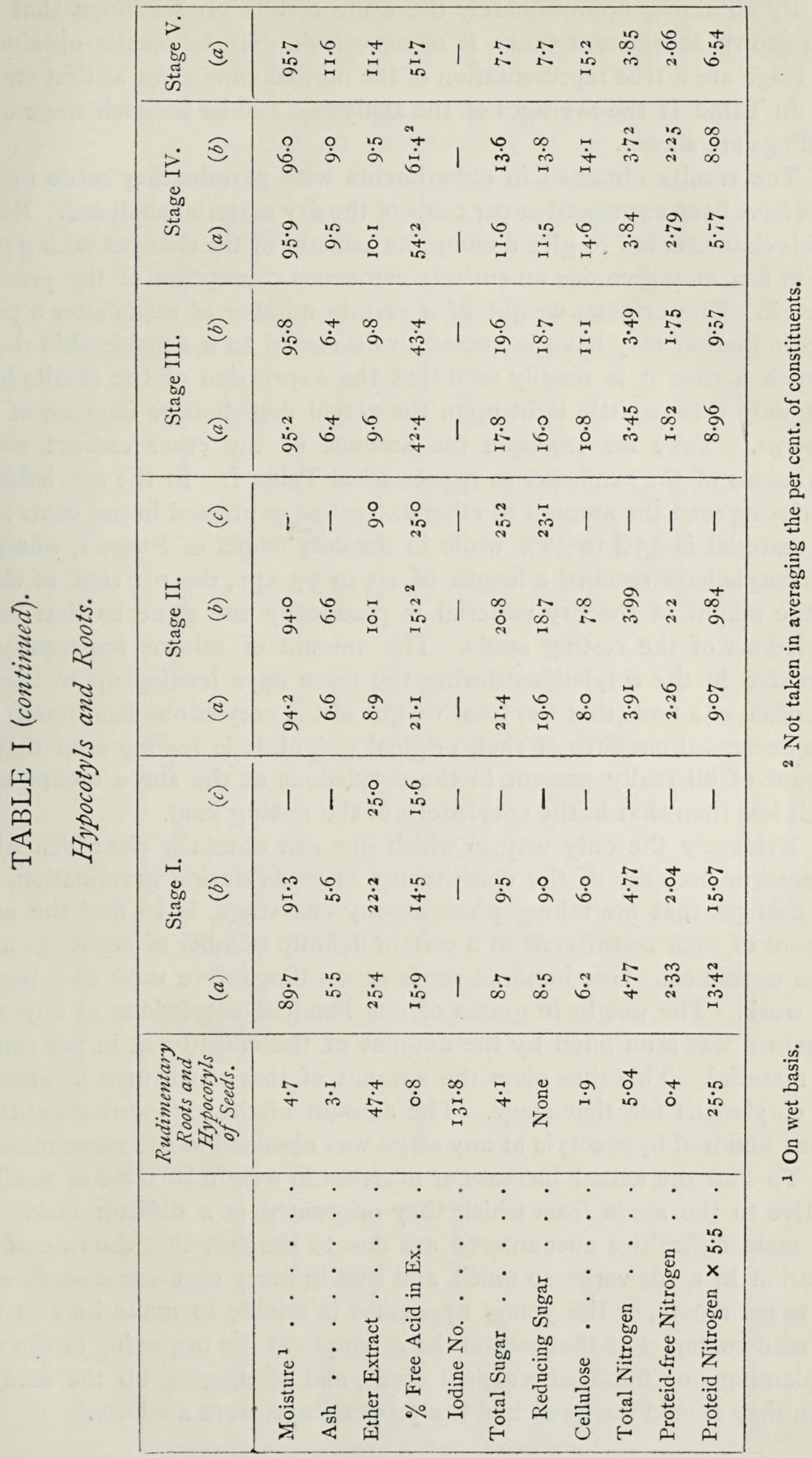


By obtaining approximately the same results on seedlings that have been grown at different times, it seems certain that the results obtained at any stage are a true representation of the normal conditions at that stage.

In Table II the averages of the analytical results for each stage of the seedlings are shown.

The results obtained in experiments with germinating seeds in most cases have been expressed as per cents of the dry material analysed. Results of this character fail to give a complete account of the changes taking place, and in fact may give one an entirely erroneous conception of the processes at work. The original weight of a certain number of seeds after a period of germination may have increased or decreased to a considerable degree. In such a case it is readily seen that the expression of the results in per cent. only throws little light upon the actual depletion or increase of constituents. Take for example the amount of the ether extract of the cotyledons of the sunflower as expressed in Table I. In the cotyledons of the resting seed the amount of ether extract as expressed in per cent. of the dry material is $55 \%$ to $56 \%$, while in the cotyledons of Stage I, where the hypocotyls have reached a length of 2.5 to $3.5 \mathrm{~cm}$., the per cent. of the oil on the weight of the dry material is practically the same as that in the cotyledons of the resting seeds. The amount of oil has apparently not decreased in the cotyledons during the three days leading up to Stage I. But when one finds that the total weight of the cotyledons has during that time decreased one-fifth of their original weight, it is readily seen that the amount of oil really present in the cotyledons at the stage mentioned is much less than that in the cotyledons of the resting seed.

Evidently the only way in which one can obtain a clear idea of the increase or decrease of the constituents in seeds during germination, or of the changes that are taking place at any one stage, is to find the actual amount of each constituent in a certain definite number of seedlings at the stage examined. One hundred seeds or seedlings were used as a basis in this work. The weight in grams of one hundred cotyledons at any stage examined was multiplied by the amount of the constituent in per cent. of dry material. This thus gives the amount of that constituent in grams in the cotyledons for that stage. The amount of the different constituents in one hundred hypocotyls at any stage was obtained in the same manner.

To find the actual increase or decrease in weight of a lot of seedlings relative to the seeds from which they originated is a difficult task. The two main difficulties encountered are due to the fact that the rate of germination in seeds varies so much, and that in every case some seeds either fail to germinate, or the young hypocotyl is unable to make its exit from the seed-coats. For that reason the attempts at the beginning of the work of planting one hundred weighed seeds, and of digging up the seedlings when they should have reached the proper stage, were a failure. 


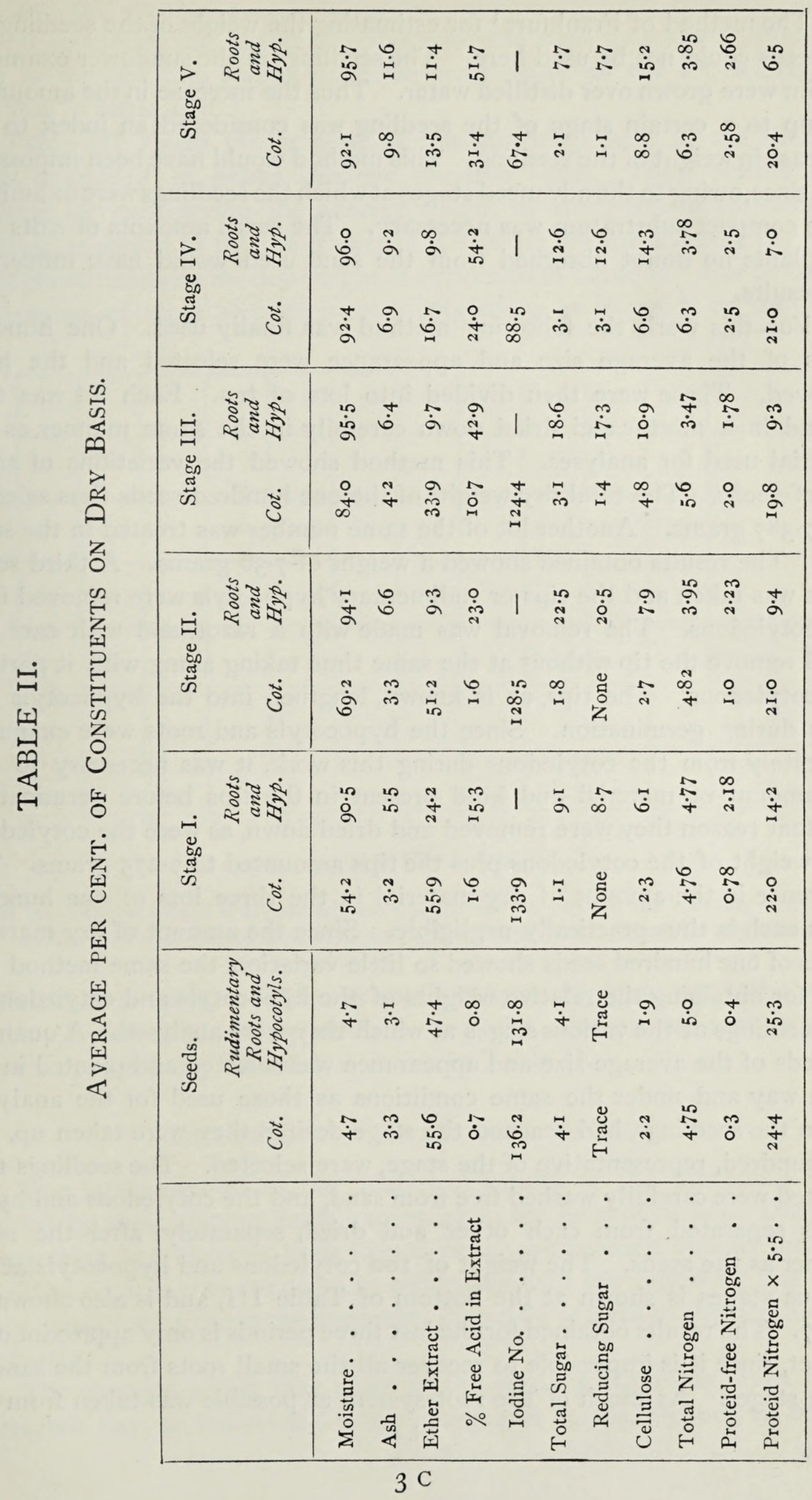


The method of Frankfurt ${ }^{1}$ for estimating the weight of the seedlings to the seeds could not be used here. The seedlings of the sunflower examined by him were grown over distilled water. Thus the increase in the amount of ash up to a certain stage of the seedling was considered an index to the decrease in weight of the seedling. This method would have been impossible here, since, owing to the advanced stages at which the seedlings were examined, some compact substratum was necessary. The small amounts of salts that the plants no doubt absorbed from the sand used would have influenced the results.

For this work the following method was finally used. One hundred seeds of the average size and appearance were selected and the hulls removed. These were then divided into lots of ten. Each lot was then ground in a mortar and dried down carefully in the same manner as the material used for analyses. This method showed the variations of small lots of seeds. The total dry weight of the one hundred seeds thus selected was $7 \cdot 387$ grams. Another lot of the same number was treated in the same way. The results obtained showed a weight of $7 \cdot 3^{6}$ grams. A third set of seeds was taken and the tips or rudimentary hypocotyls were removed from the cotyledons. The removal was made with a razor, and with care one could remove the tip without at the same time taking along with it parts of the cotyledons. The tips, as is known, lengthen into the hypocotyls and roots during germination. Since the hypocotyls and roots were examined separately from the cotyledons during this work, it was necessary to find the amount of material and kind present in the tips before germination. For that reason they were removed and dried down, as were the cotyledons. The weight of the cotyledons plus the tips amounted to $7 \cdot 275$ grams. The difference in the amount of dry material in the three lots of one hundred seeds each is thus practically negligible. Since the amount of dry material in lots of one hundred seeds showed so little variation, the same method was used for obtaining the relative weights of the hypocotyls and cotyledons of the seedlings at the various stages at which they were analysed. A quantity of seeds of the average size and appearance was selected and planted in the same way and under the same conditions as those used for the analyses. When the seedlings had reached the stage desired they were taken up, and one hundred, representative of the stage, were selected. The seedlings thus selected were carefully washed free from sand, and the cotyledons and hypocotyls separated from each other and dried, separately, after the same manner as the seeds. The weight of roo cotyledons and hypocotyls at the various stages is shown at the bottom of Table III, and is also shown by Fig. 7. The results obtained for the last three periods is only approximately correct, since it is impossible to recover all the small roots from the sand in these stages. As much of the root-system as possible was taken from the 
sand and the remnants that broke off in washing were carefully saved. Since it was found impossible to remove all the sand by washing from the roots of the last four stages, correction was made for the ash which was insoluble in nitric acid.

Table III shows the amount of constituents present at the different stages examined, in grams per one hundred seeds. These results were obtained by multiplying the average weight of 100 parts of the seed or seedlings as shown in the lower part of Table III, by the average per cent. of the constituents on the dry weight as expressed in Table II. For example, the amount of ether extract in Ioo cotyledons at Stage I, as shown in

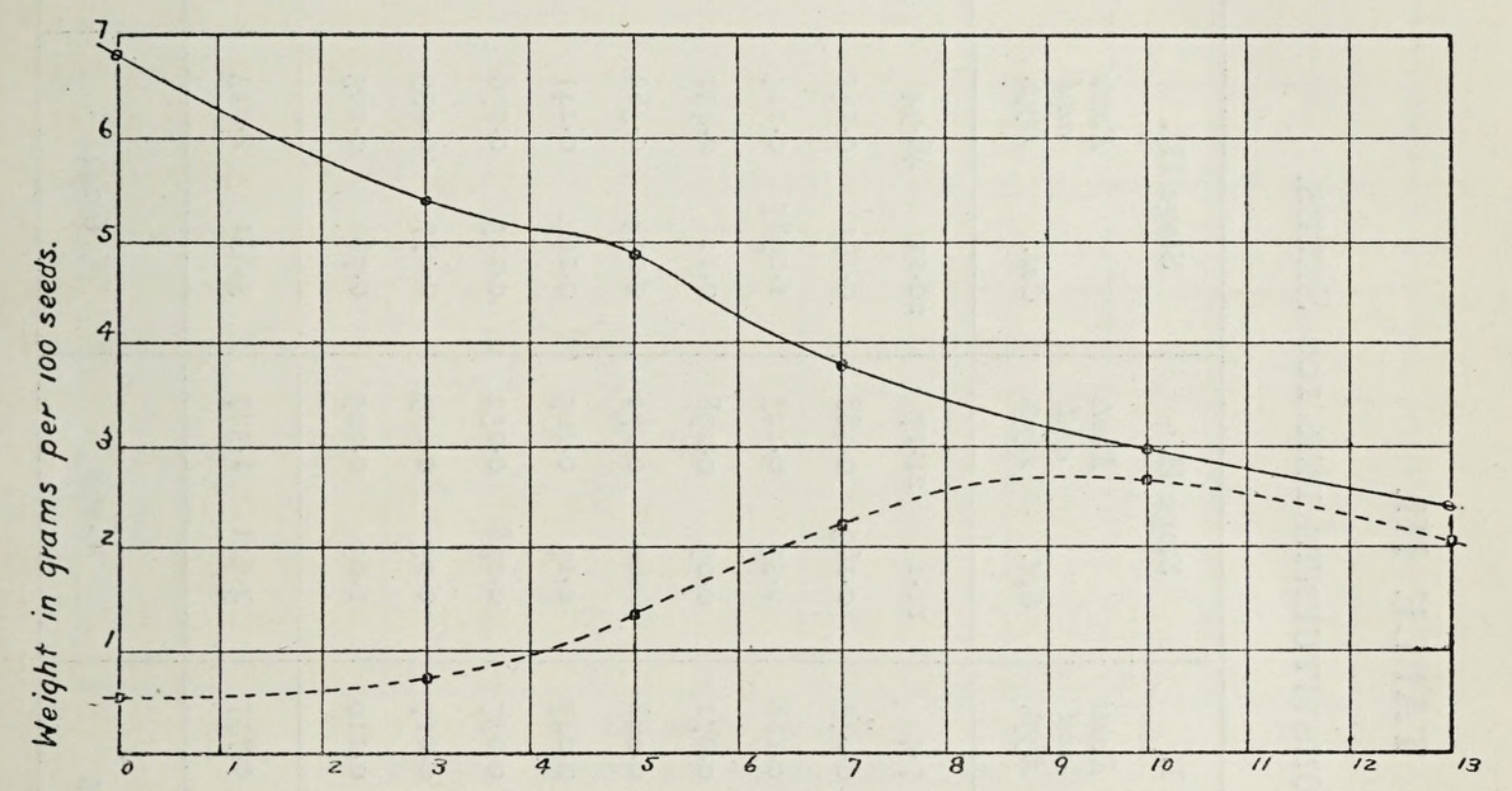

Length of Time in Days.

FIG. 7. Relative weight of Hypocotyls and Cotyledons. In this and the following figures the broken lines represent the hypocotyls and the continuous lines represent the cotyledons.

Table III, is 3.0 grams. This was obtained by multiplying $5 \cdot 368$, the weight of Ico cotyledons at that period, by 55.9 , the average per cent. of ether extract upon the dry material as shown in Table II.

\section{Discussion of Analytical Results.}

The interpretation of the analytical results in the preceding tables is aided by their diagrammatic expression in the form of curves. Diagrams representing the changes both in per cent. composition and in the total weight of constituents are given in connexion with the following discussion of the variation of the more important materials present in the germinating sunflower.

The changes which take place in the seedling from the tenth to the thirteenth day, as indicated by the tables and curves, are not to be con- 


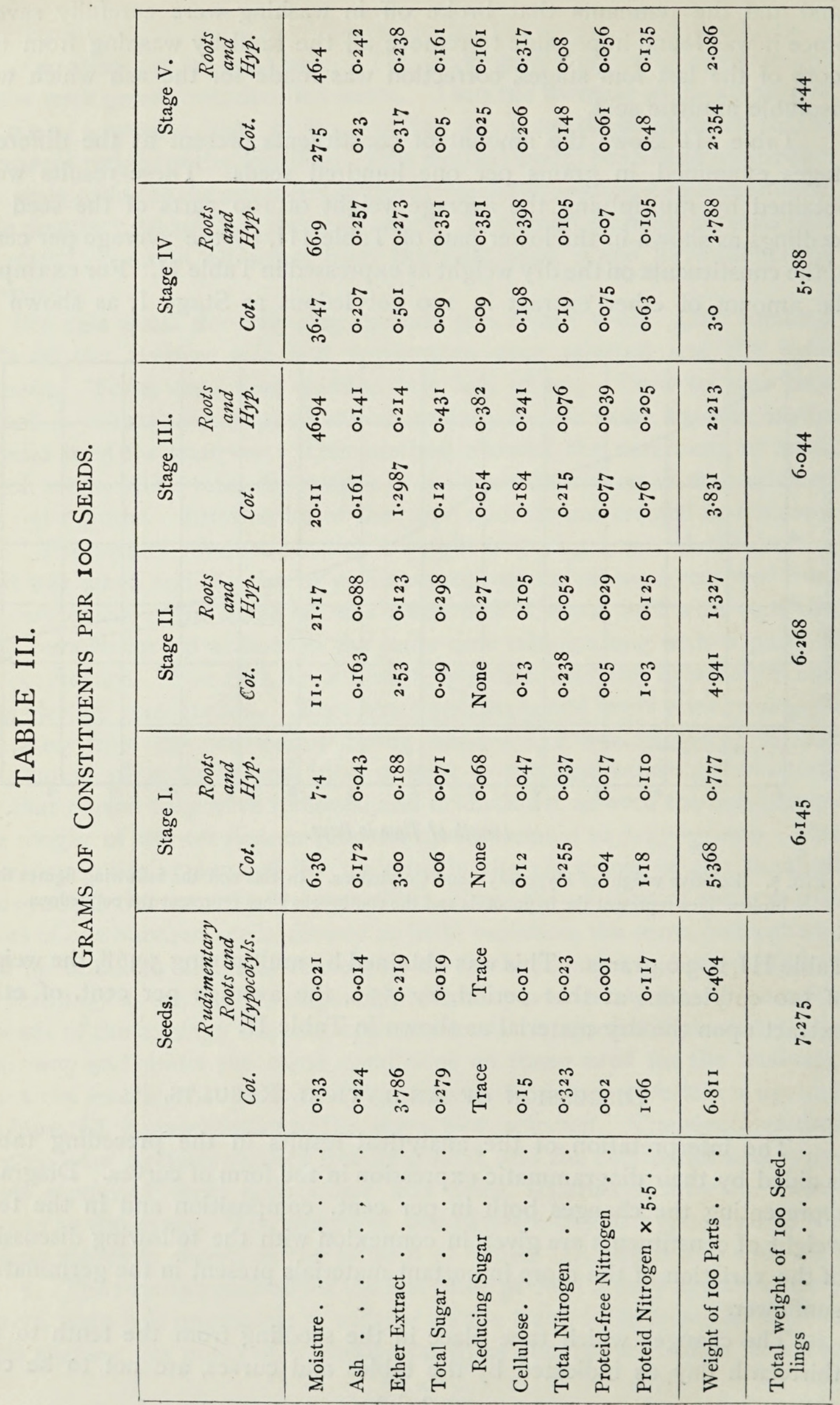


sidered as normal. The seedlings by that time have used up all the reserve material at their disposal, and under the conditions of the experiment they are deprived of the raw materials for synthetic processes, and are thus

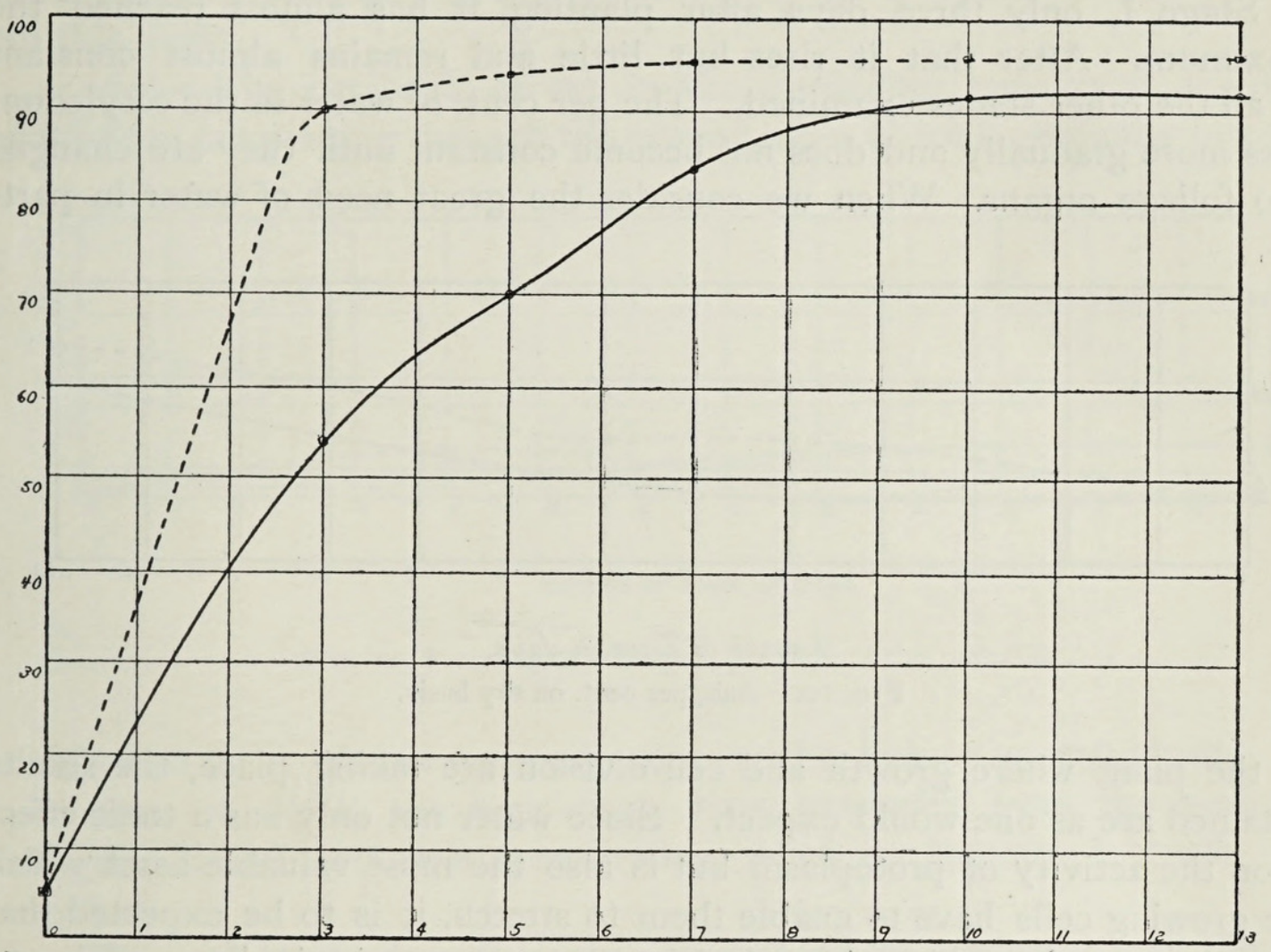

Length of Time in Days.

FIG. 8. Water Content, per cent. on wet basis.

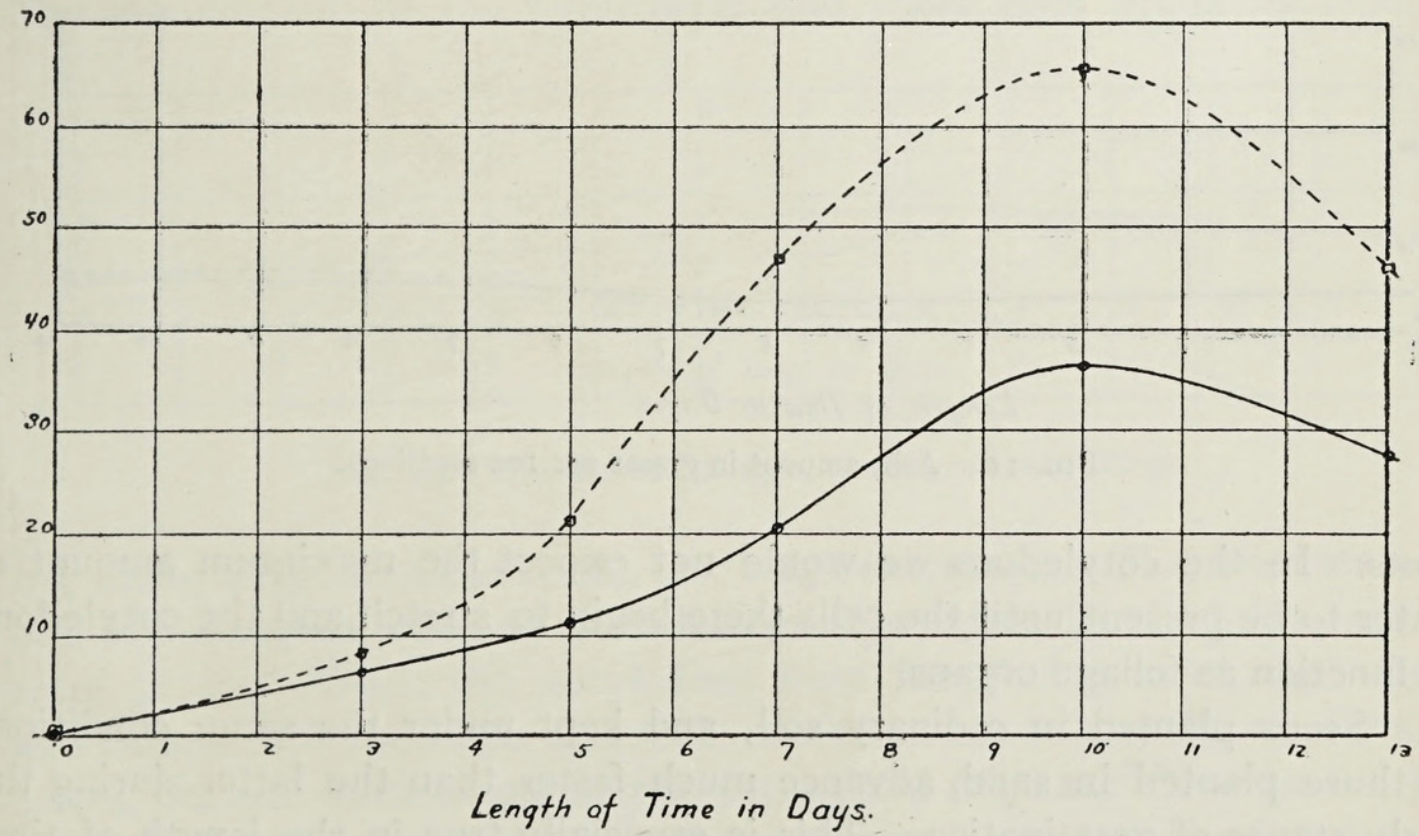

Fig. 9. Water Content, grams per roo seedlings.

in a state of starvation. The changes taking place must therefore be more or less abnormal, and are so regarded in the discussion of this work. 
Water Content.-The large amount of water which seeds and seedlings absorb during the process of germination is shown by the tables and curves. The per cent. of water in the hypocotyls and roots rises very rapidly, so that at Stage I, only three days after planting, it has almost reached the maximum. After that it rises but little and remains almost constant for all the other stages examined. The per cent. of water in the cotyledons rises more gradually and does not become constant until they are changed into foliage organs. When we consider the great need of water in parts

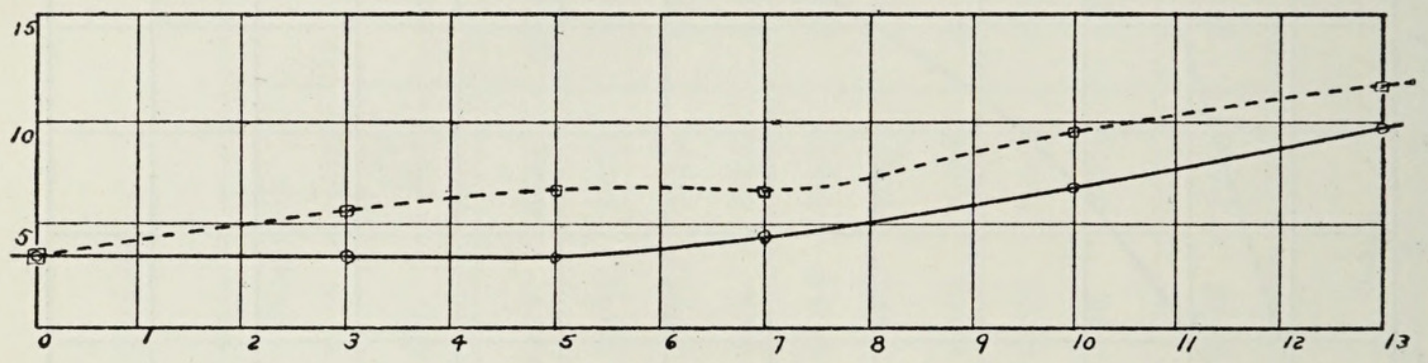

Length of Time in days.

FIG. Io. Ash, per cent. on dry basis.

of the plant where growth and cell-division are taking place, the results obtained are as one would expect. Since water not only has a tonic effect upon the activity of protoplasm but is also the most valuable asset which the growing cells have to enable them to stretch, it is to be expected that the per cent. of water would early become a constant in the hypocotyls and

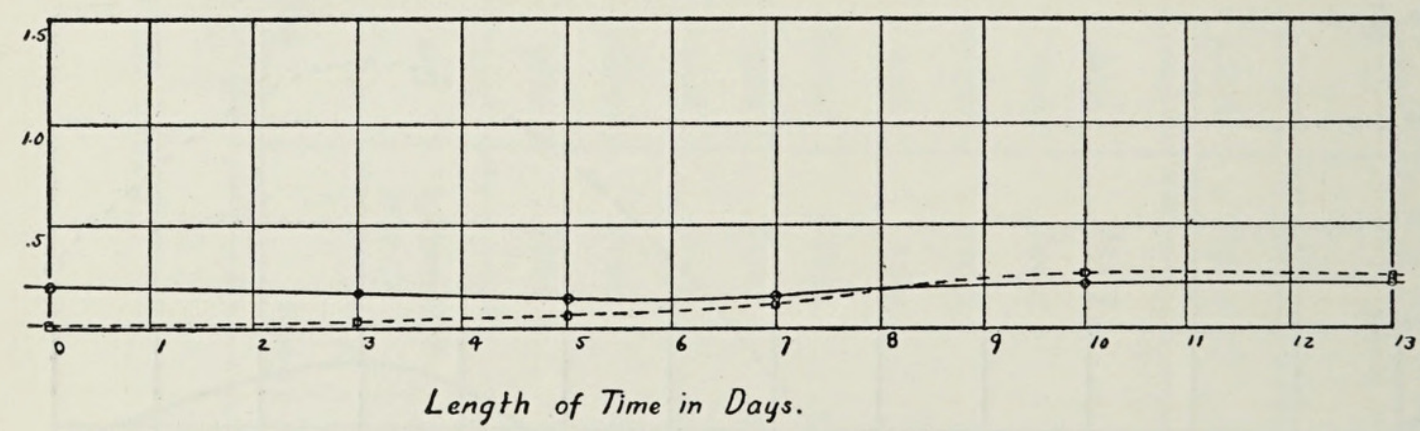

FIG. II. Ash, amount in grams per roo seedlings.

roots. In the cotyledons we would not expect the maximum amount of water to be present until the cells there begin to stretch and the cotyledons to function as foliage organs.

Seeds planted in ordinary soil, and kept under the same conditions as those planted in sand, advance much faster than the latter during the early stages of germination. This is especially true in the length of time necessary for the hypocotyls to begin to show through the seed-coats a stage in the germination reached in twelve hours with seeds planted in rich loam and forty-eight hours with those in sand. This fact is probably 
due to the low water-capacity of the sand, so that the large amount of water necessary at the beginning of germination for a maximum advance could not be furnished. This may explain why other investigators obtain certain stages of the seedlings in a shorter time than the same stages were obtained in this work.

Ash.-The per cent. of ash in the cotyledons remains at about 3.3 until they are pushing through the ground, after which it gradually increases

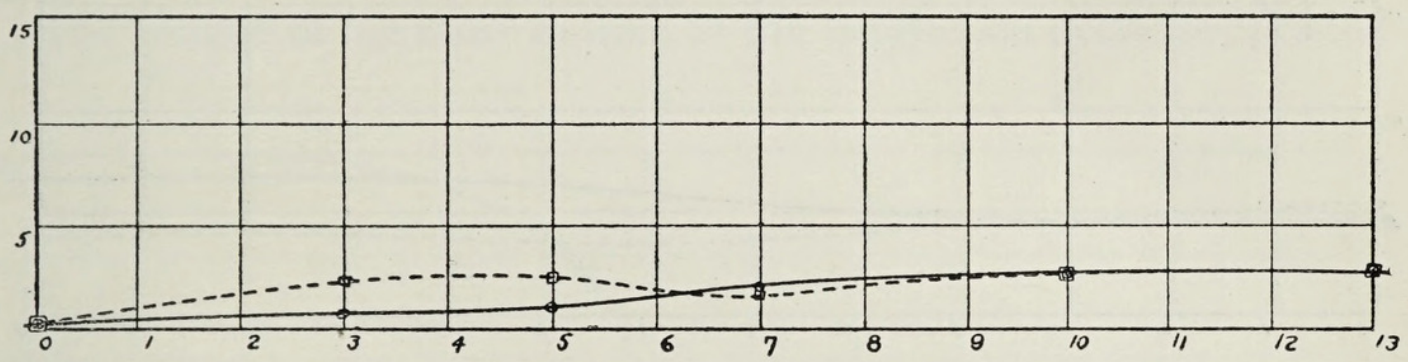

Length of Time in Days.

FIG. I 2. Proteid-free Nitrogen, per cent. of dry material.

until it reaches almost to per cent. in the last stage examined. The per cent. of ash in the hypocotyls rises gradually from the beginning of germination until the seventh day, when its increase is much more rapid.

The weight of ash in the cotyledons decreases gradually until they are beginning to function as foliage leaves, after which it increases in amount. The ash content of the hypocotyls and roots rises gradually from the

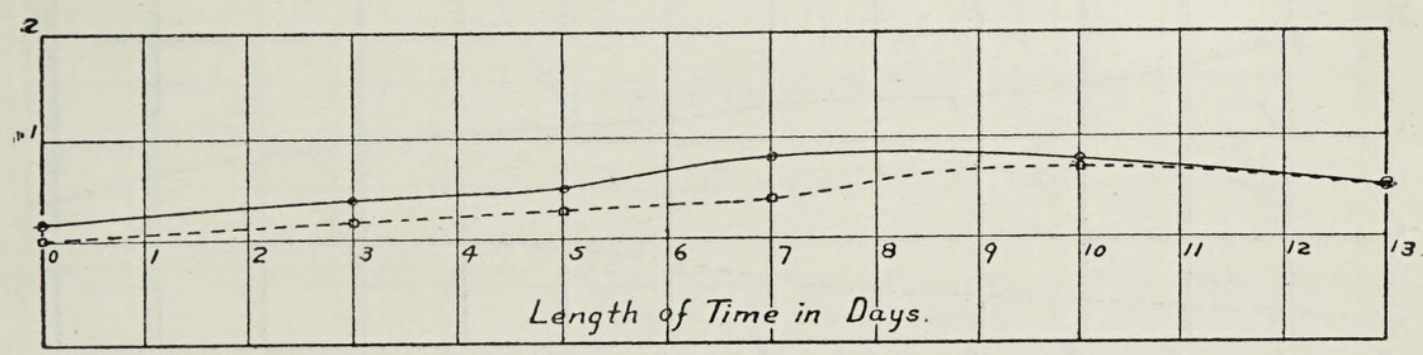

FIG. I3. Proteid-free Nitrogen, grams per roo seedlings.

beginning of germination to the last stage examined. The amounts are as one would expect when we consider the substratum in which the seedlings were grown. While the cotyledons were functioning as storage organs, and before the hypocotyls and roots could absorb to any degree for themselves, the ash constituents of the cotyledons migrated downward. After the roots became active in absorption, the small amount of mineral matter absorbed was in part transported to the cotyledons, which were now dependent upon the roots for their water supply. 
Protein.-The per cent. of proteid-free nitrogen in the resting seed is low, amounting to only 0.3 . The amount increases slowly at first in the cotyledons, but after they have reached the surface of the ground the nonprotein nitrogen amounts to $\frac{1}{3}$ of all the nitrogen present. The proteidfree nitrogen in the hypocotyls and roots varies from $\frac{1}{2}$ to $\frac{3}{4}$ of the total

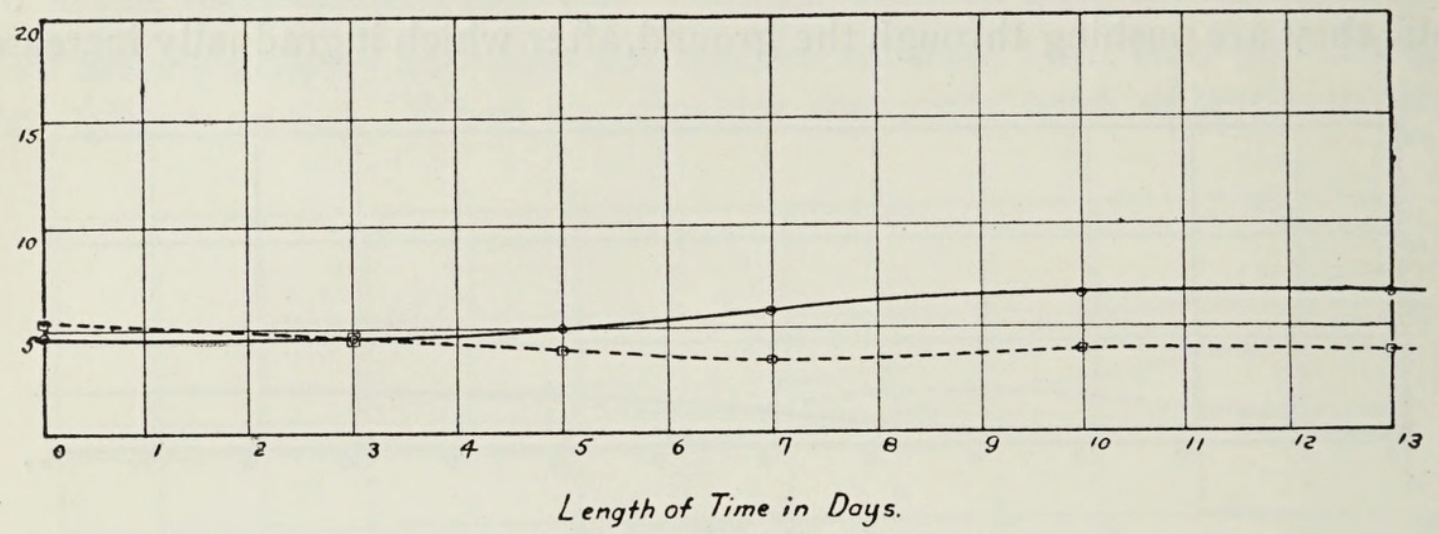

FIG. I4. Total Nitrogen, per cent. of dry material.

nitrogen present in these parts. Frankfurt found that in twelve-day seedlings of the sunflower, grown over distilled water, the glutamin and asparagin present amounted to $4.05 \%$ of the dry weight of the seedlings, and that almost $\frac{1}{3}$ of the total nitrogen present in the seedlings was in the form of these two substances and other amido-compounds.

There is a decrease in the weight of total nitrogen from the beginning

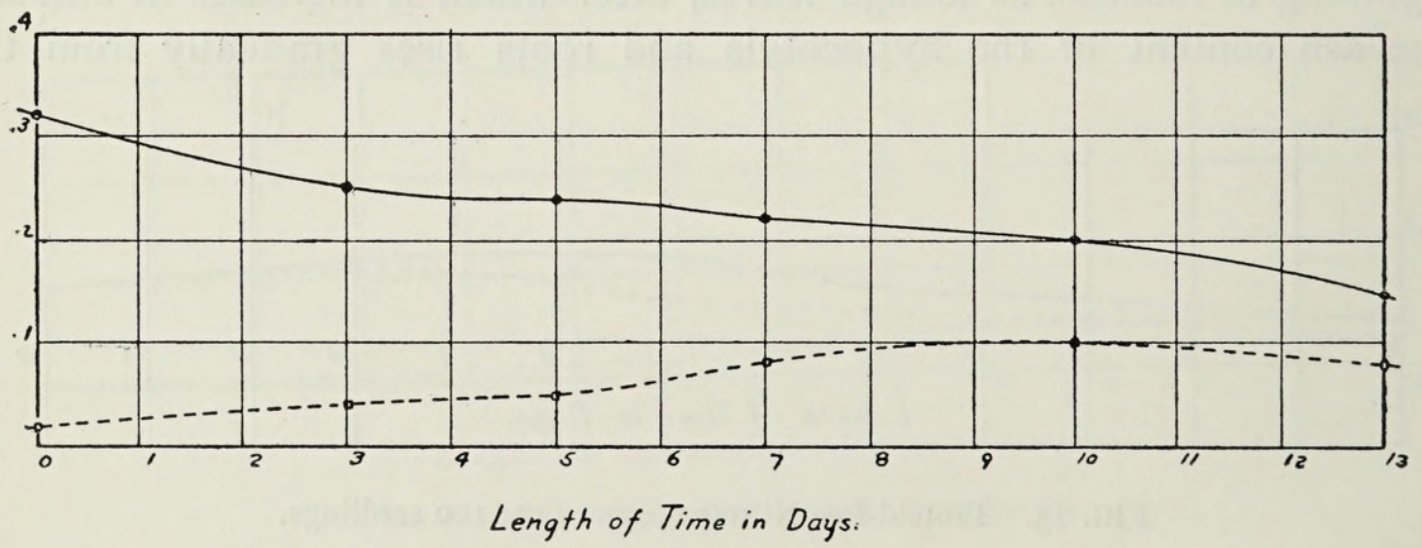

FIG, I5, Total Nitrogen, grams pẹr Ioo seedlings.

of germination to Stage I, after which the total nitrogen is a constant for the rest of the stages examined. The loss of nitrogen at the beginning of germination seems to point to the fact that there is probably an oxidation of the proteids taking place during that period.

The changes which take place in the proteid reserve during the germination of this seedling were not examined in detail, since the problem which 
here interested us most was the changes in the oily reserve, and because the protein products have been examined in some detail in this seedling, and very thoroughly in many others by Schulze and his pupils.

Ether Extract.-The per cent. of ether extract in the cotyledons remains a constant for the first three days of germination. The actual amount of extract has diminished, however, about $\frac{1}{7}$ of the amount at first present, a fact which shows that during the same period the other reserves of the seed must have been diminished also.

The weight of the ether extract in the cotyledons decreases gradually

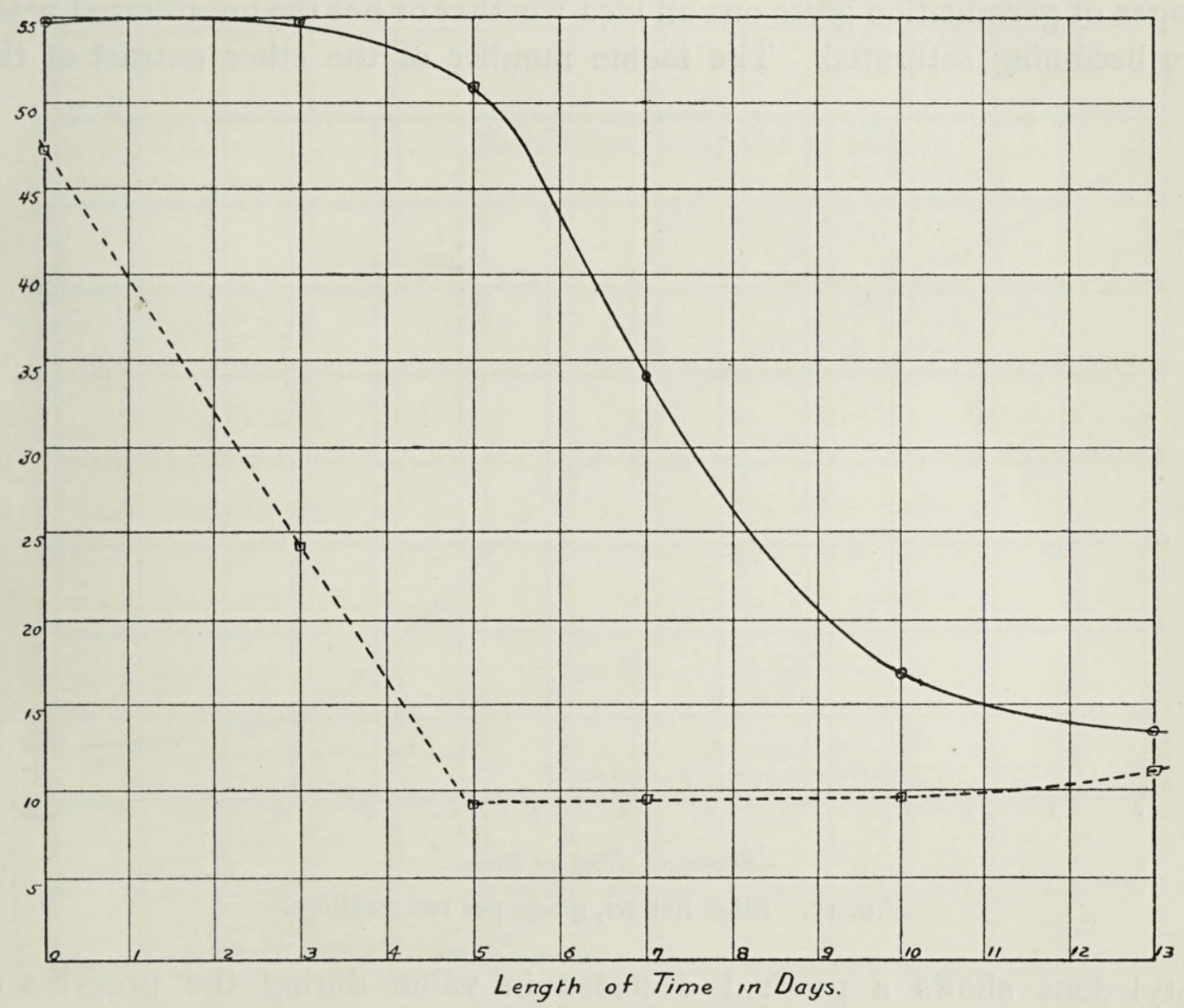

FIG. 16. Ether Extract, per cent. of dry material.

from the very beginning of germination. The most rapid decrease of this reserve takes place between the period when the cotyledons are just beginning to break through the ground and the time when they are fully expanded. The per cent. of ether extract in the hypocotyls and roots falls very rapidly, and after the cotyledons are above ground it remains almost constant. The amount of the ether extract in grams, however, decreases only slightly during the early stages of the seedling, but when the greatest decrease is taking place in the cotyledons, the oil in the hypocotyls and 
roots begins to increase in amount and reaches the maximum in the ten day seedling.

The changes which the oily reserves undergo in the progress of the development of the seedling are difficult to determine. This is due to the fact that these reserves in seeds are composed of a mixture of glycerides which have never been separated from each other, and to the lack of knowledge of the exact structure of some of the acid radicles of these glycerides. Nevertheless, certain processes and results can help in a measure to throw some light upon the changes which take place in germination.

The value of the iodine number of the ether extract during different stages of germination gives one an idea whether or not the unsaturated acids are becoming saturated. The iodine number of the ether extract of the

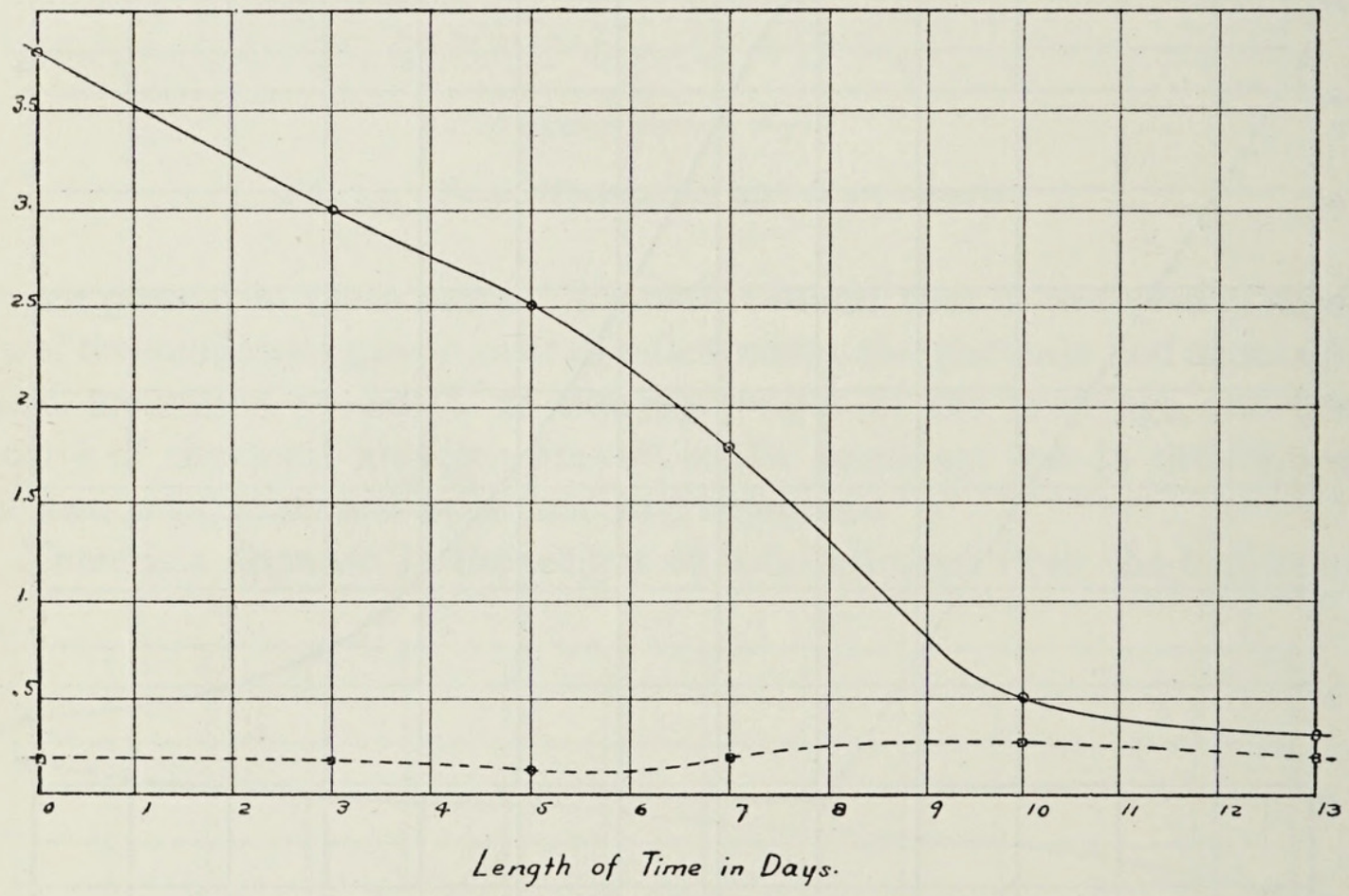

FIG. I 7. Ether Extract, grams per roo seedlings.

cotyledons shows a gradual decrease in value during the progress of development of the seedling. The value decreases from $I_{3} 6 \cdot 2$ for the ether extract of the seed to 67.4 for that of the thirteen-day seedling. The value for the last two stages examined may be a little too low owing to the chlorophyll present in the ether extract, but the value of the other stages is not influenced by this pigment. The decrease of the iodine number seems to indicate that the unsaturated acid radicles of the oil are becoming saturated, probably by the addition of oxygen. Von Fürth found no such evidence of a decrease in the value of the iodine number of the oil of the seed and seedling of the sunflower. His determinations, however, were limited to only one stage of the seedling, and cannot be given the same weight as the extensive work of Schmidt on the fatty acids of the sunflower 
seedling, and many other species, showing plainly a decrease in the value of the iodine number as germination progresses.

During certain periods of germination the weight of the seedlings decreases but little, and even increases. For example, the total weight of the seedlings in Stage II, when the hypocotyls have reached a length of $7 \cdot 5$ to II $5 \mathrm{~cm}$., is a little more than the same number of seedlings two days younger, when the length of the hypocotyls is only 2.5 to $3.5 \mathrm{~cm}$.; the decrease in weight from Stage II to Stage III is very small also. These facts point to an absorption of oxygen by the oil, as suggested by Hellriegel and others, but it can only be definitely proven by an ultimate analysis of the oil.

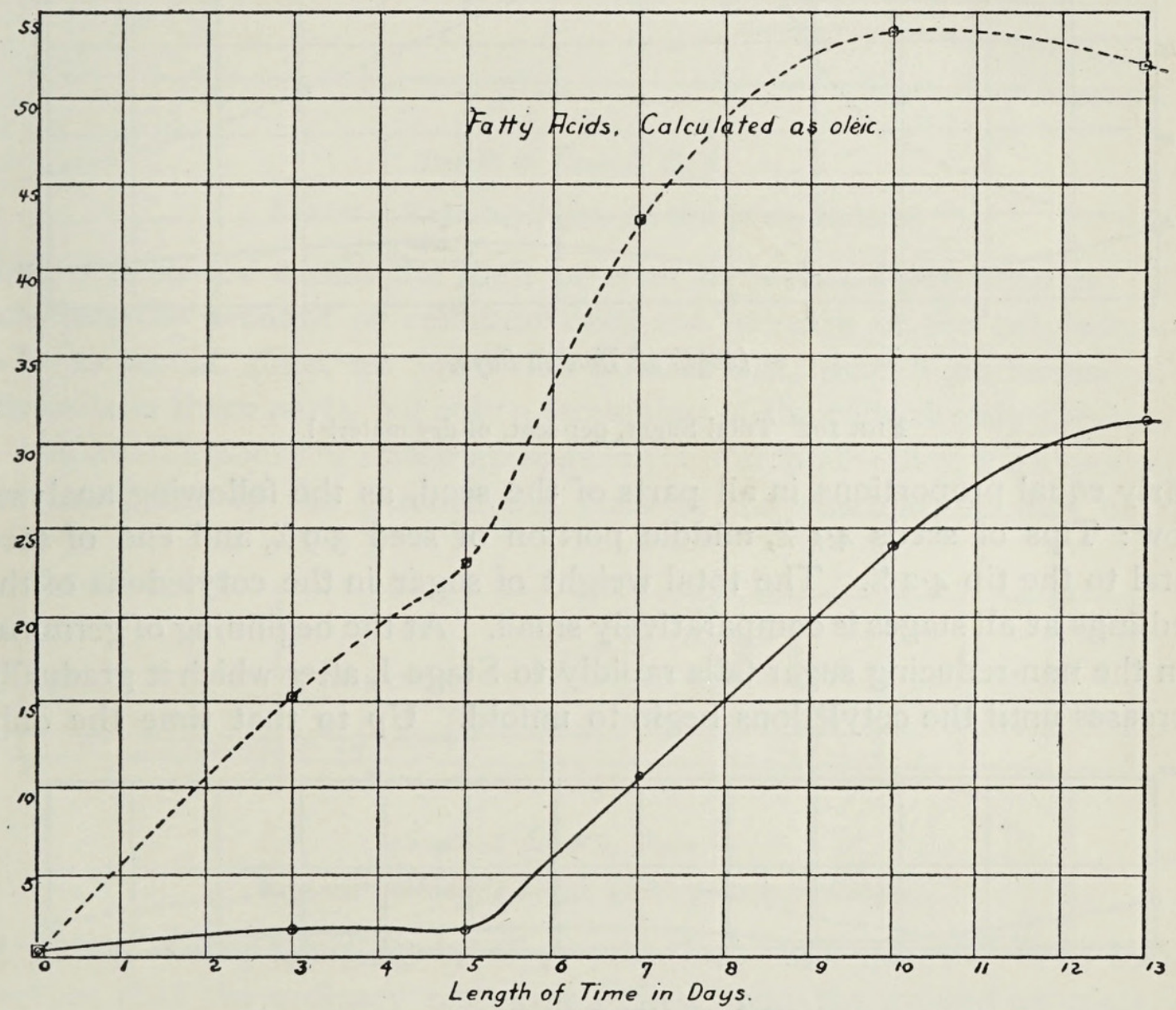

FIG. I8. Free Fatty Acid, per cent. of ether extract.

The free fatty acid in the oil of the cotyledons of the resting seed is less than one per cent. During the early stages of germination this per cent. increases very slowly, and when the seedlings are breaking through the ground it amounts to only I.6. From that period it rises rapidly, and when the plant has reached the ten-day stage it amounts to $\frac{1}{3}$ the ether extract.

The acid of the ether extract of the hypocotyls and roots increases rapidly from the beginning, and in the later stages composes over $\frac{1}{2}$ of the oily content of these parts. These facts indicate that during the course of 
germination at least a part of the oil is broken up into glycerine and free fatty acid. Glycerine, however, has never been detected as yet in seedlings, since it seems to be used at once by the plant, or is changed immediately, so that no accumulation of it takes place.

Carbohydrates.-The total amount of sugar in the resting seed amounts to $4.1 \%$. Of this amount all except a trace is non-reducing sugar, and has been identified as cane sugar by Frankfurt. ${ }^{1}$ This sugar is distributed in

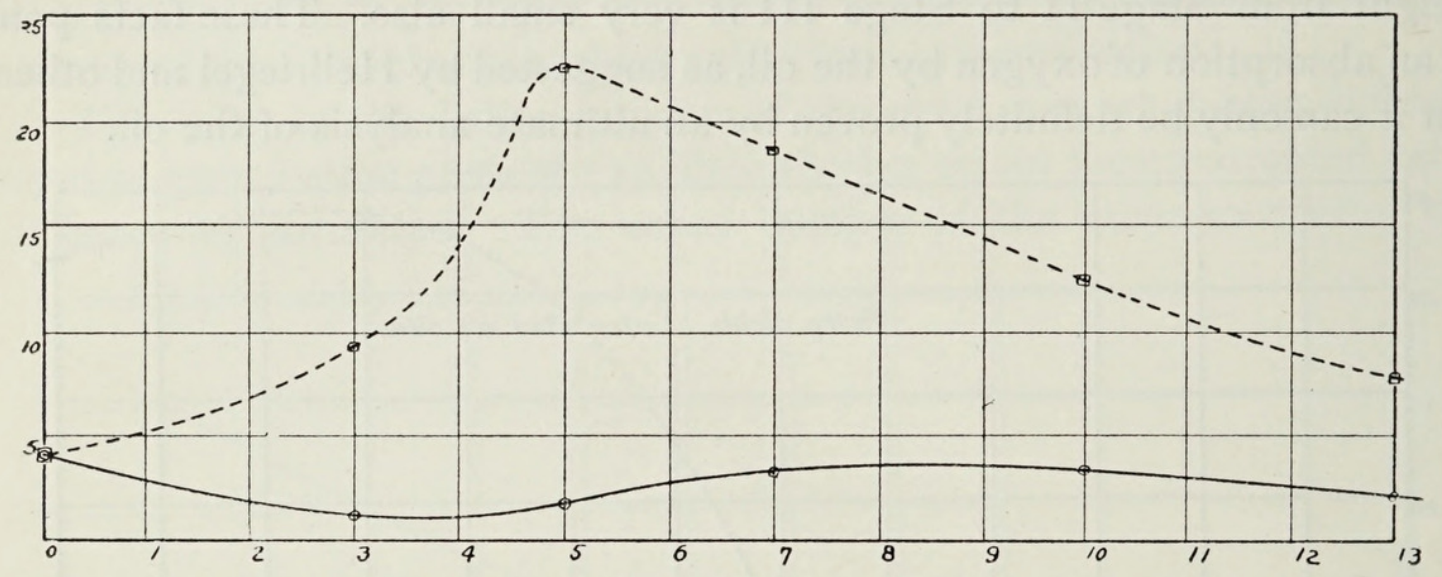

Length of Time in Bays.

FIG. I9. Total Sugar, per cent. of dry material.

nearly equal proportions in all parts of the seed, as the following analyses show: Tips of seeds $4.1 \%$, middle portion of seed $3.9 \%$, and end of seed distal to the tip $4.2 \%$. The total weight of sugar in the cotyledons of the seedlings at all stages is comparatively small. At the beginning of germination the non-reducing sugar falls rapidly to Stage I, after which it gradually increases until the cotyledons begin to unfold. $U p$ to that time the only

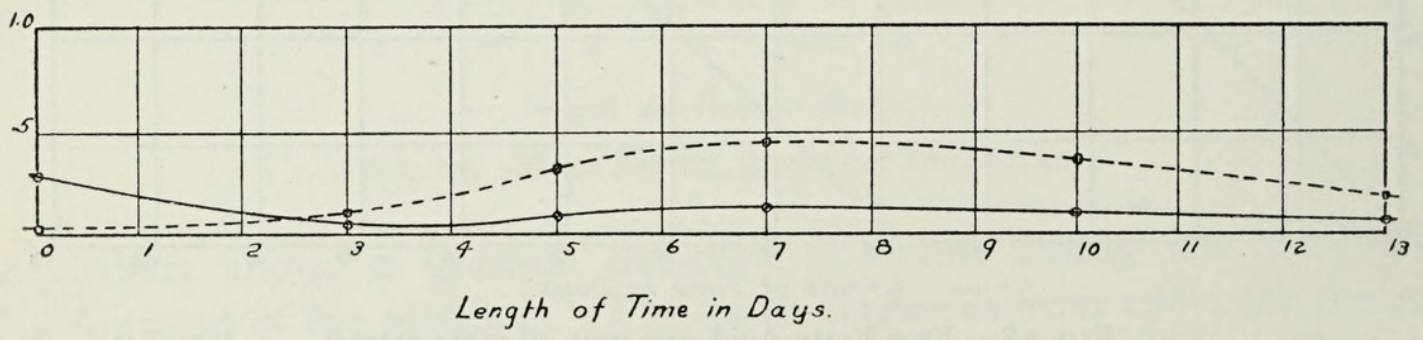

FIG. 20. Total Sugar, amount in grams per roo seedlings.

sugar present in the cotyledons is of the non-reducing kind, but when the cotyledons assume the foliage function reducing sugar begins to make its appearance, and in the ten-day seedling it is the only sugar present. The per cent. of total sugar rapidly rises in the hypocotyls and roots, and when they have reached a length of 3 to $4 \frac{1}{2}$ inches it amounts to $20 \%$ of the dry weight. After that period it decreases, and in the ten-day seedling amounts to $12.6 \%$. The actual amount of sugar, however, reaches its 
maximum at Stage III, when the cotyledons have just spread out, and from that time on it gradually decreases.

The actual amount of cellulose in the cotyledons changes but little during the different stages of the seedlings examined, and the slight varia-

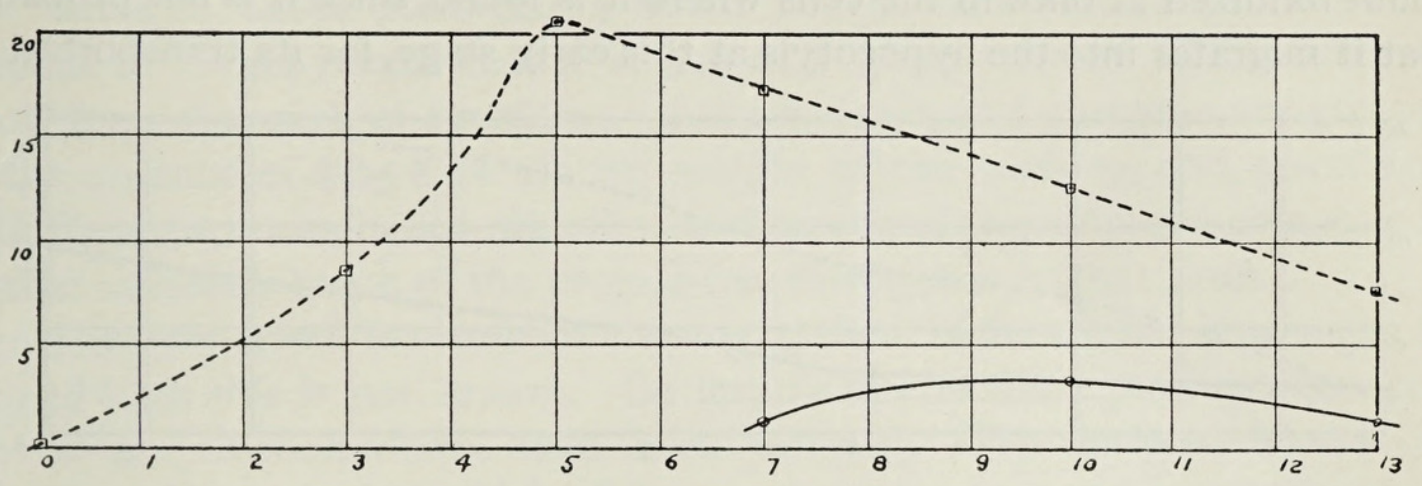

Length of Time in Days.

FIG. 2I. Reducing Sugar, per cent. of dry material.

tions noticed are within the limit of error of such a determination. The fact that the amount of cellulose does not increase in the cotyledons is to be expected, since, as Sachs first pointed out, there is no formation of new cells in these parts, but only a stretching of the cells already present.

A small amount of starch appears in the starch sheath of the hypocotyls and roots and in the parenchyma cells of the vascular bundles of the

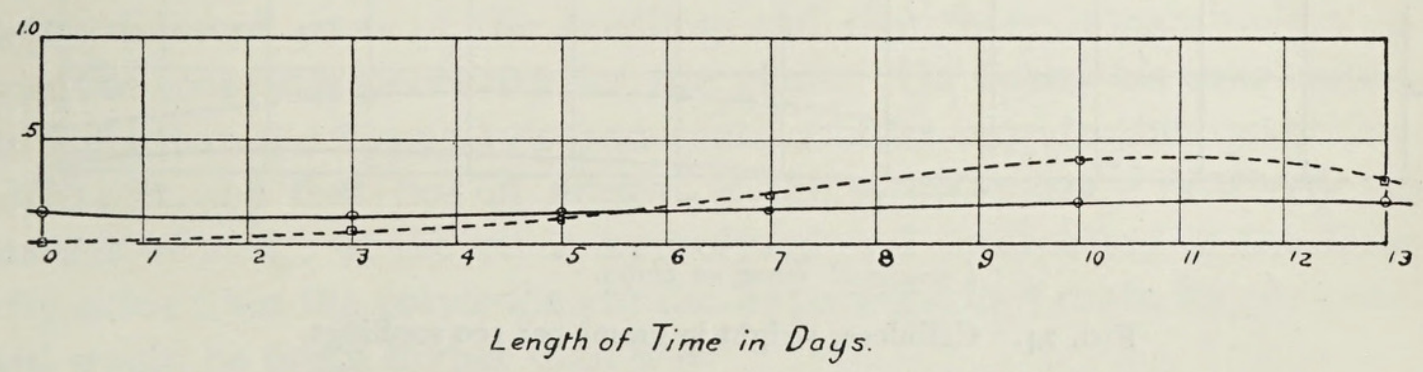

FIG. 22. Reducing Sugar, grams per 100 seedlings.

cotyledons during the progress of germination. The quantity is so small, however, that the ordinary test with iodine upon the ground-up material fails to show any results. Under the microscope, however, the grains are plainly visible when sections are cut and stained with iodine. This fact is worthy of note, since it serves to show the danger of judging the chemical changes which take place in plants by micro-chemical means, unless they are substantiated by analytical determinations. The amount of starch present here is very small compared to the other carbohydrates, yet by micro-chemical methods it is made very conspicuous, and the amount is liable to be over-estimated.

Initial Losses.-Judged on the basis of consumption of material the greatest intensity of respiration in the seedling seems to be from the time of 
planting to Stage I, when the hypocotyls and roots are 2.5 to $3.5 \mathrm{~cm}$. in length, and the formation of new cells scarcely begun. The seedling up to that time has lost $\frac{1}{7}$ of the original weight of the seeds. The cotyledons have lost $\frac{5}{6}$ of the sugar which was present in the resting seed. This is no doubt oxidized at once in the cells where it is found, since it is not probable that it migrates into the hypocotyls at this early stage, for its transportation

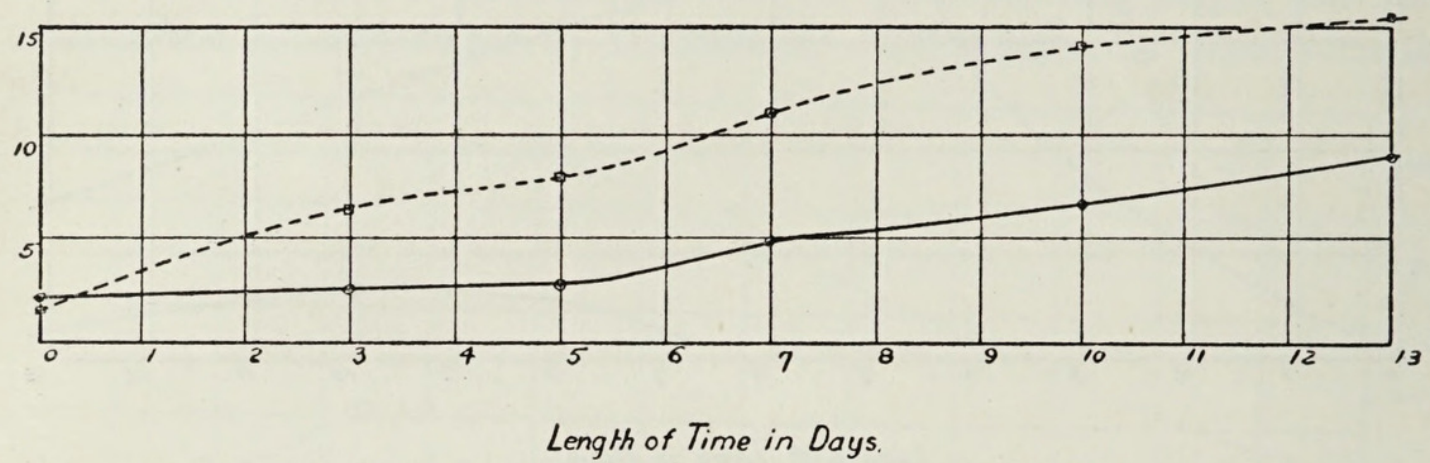

FIG. 23. Cellulose, per cent. of dry material.

from all parts of the cotyledons to those parts would be improbable through cells packed so full of reserve material.

In this period nearly $\frac{1}{4}$ of the proteid disappears. The loss of the total nitrogen during that period represents approximately that amount. The amount of oil during the same period has diminished $\frac{1}{7}$ of its original amount. These results give one an idea of the great amount of energy

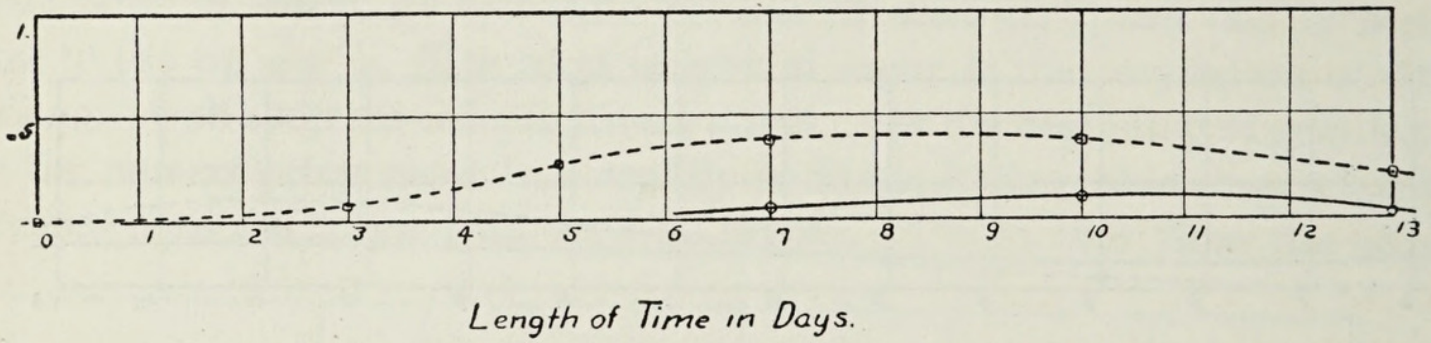

FIG. 24. Cellulose, weight in grams per 100 seedlings.

required at the very beginning of germination to set the life-processes, as it were, in motion. This fact is clearly indicated by the loss of nitrogen in the first stages of germination, a process which is very unusual in the metabolism of plants, for under ordinary conditions the nitrogen of the protein-compounds is never liberated from the plant.

Problem of Oil-transformation.-The marked increase in the amount of carbohydrate in the seedling during germination raises the question as to its origin, which in the sunflower could only be the proteid or the oil. It is difficult to understand how the proteid can be the source of any material portion of the carbohydrate which makes its appearance during the growth of the seedling. For example, compare Stages I and III ; the total amount of cellulose and sugar in 100 seedlings at Stage I amounts to $0.3 \mathrm{gram}$, and the proteid nitrogen $\times 5.5$ amounts to $\mathrm{I} \cdot 3$ grams; at Stage III, when the 
amount of sugar is at its maximum, the total sugar and cellulose amount to 0.98 gram, a gain of 0.68 gram, and the proteid nitrogen $\times 5.5$ amounts to I gram, a loss of $0.3 \mathrm{gram}$. If the protein loss of $0.3 \mathrm{gram}$ had been used entirely for the production of carbohydrate with the formation of carbonfree nitrogen waste products, it would not be sufficient to produce the amount of carbohydrate shown in the 0.68 gram increase. Moreover, we know from the work of Frankfurt ${ }^{1}$ that asparagin and glutamin are present to the amount of $4.05 \%$ of the dry weight of the seedling, and associated with these two compounds are other carbon-containing nitrogen-compounds so that evidently much of the proteid-free nitrogen is in that form.

The only possible source of the sugar, then, is the oil, but how sugar is formed from this is not known. So far, no intermediate products between the oil and carbohydrate have been isolated. The various theories in regard to the manner in which oil is converted into sugar are mentioned in the historical review. It seems evident that a further knowledge of this problem can only be attained by a more detailed study of the oil and the products which are derived from it during the period of germination.

Investigators have all been of the opinion that oil is converted into carbohydrate during the germination of oily seeds, but the part of the seedling where this takes place is in dispute.

Schmidt, ${ }^{2}$ in his extensive experiments on the transportation of oil in plants, worked with the seedling of the sunflower amongst others. $\mathrm{He}$ believed that in the germination of this plant the oil was transported as such to the different parts of the seedling and that there it was broken up to form the materials necessary for the plant. He based his conclusions on the facts that the hypocotyls and roots contain considerable quantities of neutral fat, and that the oil present in the seedling has a relatively small amount of acid. If the oil is hydrolysed and transported in the form of fatty acids from the cotyledons to the hypocotyls and roots, its per cent. of acid would be much higher than it is.

Schmidt found that the cell-walls of plants were permeable to oil in the presence of free fatty acid, and that the greater the quantity of acid the more readily did the oil permeate the cell membranes. His theory, then, that oil can be transported as such to these parts is based upon experiments which seem conclusive that such transportation is possible.

Certain authors hold that the oil in the cotyledons is broken up into free fatty acid and glycerine and then transported to the parts where it is needed, either as the free acid or as soap, or that it is broken down into carbohydrate in the cotyledons and transported to the growing parts in that form. The oil present in the hypocotyls and roots they regard as a transformation product of the materials which have been brought there in excess. The transportation of oil as such to the growing regions and its de-

$$
{ }^{1} \text { 1. c. }{ }^{2} \text { 1. c. }
$$


composition there would from the standpoint of energy be most advantageous to the plant. This, however, cannot be taken as a criterion for the processes which take place in life, since often they seem to represent, as far as we can see, a useless waste of energy. To be certain, however, that oil-migration does take place, the oil which is found in the growing parts must be shown to be of the same composition as that of the reserve from which it is supposed to have come, and the possibility of oil-migration through plant-membranes must be more firmly established than it is at present. If the oil is not changed in its transportation, it is the only insoluble reserve, so far as is known, which is not. The fact that the amount of free acid in the oil does not reach a high amount at the earlier stages of germination does not necessarily indicate that the oil is being transported as neutral oil from its place of reserve. The oil may be broken down in the cotyledons and the products transported as soon as they are formed, so that no accumulation of them takes place. In fact, in the later stages, the amount of acid rises to $\frac{1}{3}$ of the oily content of the cotyledons, and to over $\frac{1}{2}$ of that of the hypocotyls and roots. This appears, too, at a time when the greatest changes are taking place in the seedling, and indicates that an accumulation of acid takes place because of the inability to transport it as rapidly as it is formed.

\section{Summary.}

During the first three days after the planting of the seeds, the rudimentary roots and hypocotyls reach a length of 2.5 to $3.5 \mathrm{~cm}$.

The cotyledons have absorbed a quantity of water in that time equal to $50 \%$ of their weight, while the per cent. of water in the hypocotyls and roots amounts to $90 \%$ of their weight. During this time the most intensive respiration in the development of the seedling apparently takes place, for at the end of this period the total weight of the seedling amounts to only $\frac{7}{8}$ that of the resting seed. Five-sixths of the sugar content of the cotyledons, $\frac{1}{7}$ of the oil, and almost $\frac{1}{4}$ of the protein has disappeared. The rudimentary hypocotyls and roots at first increase in length by the stretching of the tip, but later in this period the cells of the growing point of the root become active and the increase in length is brought about in the usual way.

As the development of the seedling advances, the depletion of the reserves in the cotyledons advances from the point nearest the hypocotyls to the end remote from it. The most marked change in the reserve products takes place between the time when the cotyledons are breaking through the ground and the period when they are fully developed into foliage organs. This occurred between the fifth and tenth days under the conditions of this experiment. 
The protein reserve during the progress of germination is broken up apparently into the ordinary cleavage-products, which are transported into the regions of the roots and hypocotyls, where they are used in the formation of new cell contents.

The oil during the advance of the seedling is, in part at least, broken down into free fatty acid and glycerine. The quantity of free acid in the oil of the cotyledons is comparatively low until the seedling is well developed, while the content of acid in the oil of the hypocotyls and roots rises rapidly at the very beginning of germination and remains high during the different stages examined. Both the neutral oil and the free acid probably take up a quantity of oxygen into their structure, as the decrease in the iodine number indicates.

The marked increase in the amount of sugar during the progress of development of the seedling makes it certain that it has its origin in the oily reserve. The cotyledons at no time contain any appreciable amount of sugar, but it is present in abundance in the hypocotyls at all stages. The amount of cellulose in the cotyledons remains the same, since no new cells are formed there. The sugar produced from the oil is the material used by the plant for the formation of new cell-walls in the growing parts.

Whether the oil as such is transported from the cotyledons to the growing parts and then transformed, or whether the transformation takes place in the cotyledons previous to transportation, cannot be determined from our present knowledge of the subject.

In conclusion, I wish to express my sincere thanks to Professor A. W. Evans and Assistant-Professor A. L. Dean, for their able assistance in all parts of this work.

Sheffield Scientific School, YALE UNIVERSITY.

\section{LITERATURE CITED.}

1. De Saussure, T. : Ueber das Keimen der Oelsamereien. Froriep's Notizen, xxiv, 1842, p. 24.

2. Letellier : Jour. für prakt. Chemie, lxiv, 1855 , p. 94.

3. Hellriegel, H. : Beitrag zur Keimungsgeschichte der ölgebenden Samen. Jour. für prakt. Chemie, 1xiv, 1855 , p. 94 .

4. SAchs, J.: Ueber das Auftreten der Stärke bei der Keimung ölhaltiger Samen. Bot. Ztg., I 859 , pp. $177-83$ and $185^{-8}$.

5. - Ueber die Keimung des Samens von Allium Cepa. Bot. Ztg., 1863, pp. 57 and 65. 
6. Peters : Versuchs-Stationen, iii, I86r, p. $\mathbf{I}$.

7. Fleury, M. : Recherches chimiques sur la germination. Ann. chim. et phys., iv, $4^{e}$ série, I 865, p. 38 .

8. Müntz, M.: Sur la germination des graines oléagineuses. Ann. chim. et phys., xxii, $4^{e}$ série, I $87 \mathrm{I}, \mathrm{p} .472$.

9. Laskovsky, N.: Ueber einige chemische Vorgänge bei der Keimung der Kürbissamen. Versuchs-Stationen, xvii, 1874 , p. 219.

10. Detmer, W. : Phys.-chem. Untersuchung über die Keimung ölhaltiger Samen. Leipzig, 1875 .

11. : Vergleichende Physiologie des Keimungsprocesses. Jena, 1880, pp. 336-8.

12. Green, J. R. : On the Germination of the Seeds of the Castor-oil Plant. Proc. Roy. Soc., xlviii, 1890 , p. 370 .

13. Schмidt, R. H.: Ueber Aufnahme und Verarbeitung von fetten Oelen-Pflanzen. Flora, lxxiv, I89i, p. 300.

14. Leclerc du Sablon: Sur la germination du Ricin. C. R. Ac. Sc., Paris, cxvii, I893, p. 524.

15. cxix, I894, p. 6 го.

16. Frankfurt, S. : Ueber die Zusammensetzung der Samen von Cannabis sativa and Helianthus annuus. Versuchs-Stationen, xliii, I894, p. I43.

17. Leclerc du SAblon: Sur la germination des graines oléagineuses. Rev. gén. Bot., vii, r895, pp. I $45,204,258$.

18. Wallerstein, M. : Die Veränderungen des Fettes während der Keimung und deren Bedeutung für die chemisch-physiologischen Vorgänge der Keimung. Abst. Chem. Centralbl., i, 1897, p. 63 .

19. Merlis, M.: Ueber die Zusammensetzung der Samen und der etiolierten Keimpflanzen von Lupinus angustifolius. Versuchs-Stationen, xlviii, $1897, \mathrm{p} .419$.

20. Leclerc DU Sablon: Sur la germination des amandes. Rev. gén. Bot., ix, I897, p. 5.

21. - : Sur les reserves oléagineuses de la noix. Rev. gén. Bot., ix, 1897, p. $3 \mathrm{I} 3$.

22. Hanriot, M. : Sur la transformation de la graisse par oxydation directe. C. R. Ac. Sc., Paris, cxxvii, 1898 , p. 56 r.

23. Mąuenne, L.: Sur les changements de composition qu'éprouvent les graines oléagineuses au cours de la germination. C. R. Ac. Sc., Paris, cxxvii, 1898, p. 625.

24. Sani, G.: Ueber die Keimung der Olive. Chem. Centralbl., i, I 900, p. 773.

25. MAZÉ, M.: Recherches sur la digestion des réserves dans les graines, la germination et leur assimilation par les plantules. C. R. Ac. Sc., Paris, cxxx, 1900, p. 424 .

26. Kirkwoov and Gies: Chemical Studies of the Cocoa-nut, with some Notes on the Changes during Germination. Bull. Torr. Bot. Club, xxix, I902, pp. 32 I-59.

27. Jegorow, M. : Ueber Stoffmetamorphose bei der Samenkeimung von Cucurbita maxima. Bot. Centralbl., ci, 1906, p. 597.

28. von Fürth, O.: Ueber das Verhalten des Fettes bei der Keimung ölhaltiger Samen. Hofmeister's Beiträge zur chem. Physiol. und Path., iv, 1904, p. 430.

29. Green, J. R., and Jackson, H.: Further Observations on the Germination of the Castor-oil Plant. Proc. Roy. Soc., lxxviii, 1905, p. 69.

30. Osborne and Campbell: Proteids of the Sunflower Seed. Amer. Chem. Soc., xix, 1897, p. 487 .

31. Lowenstein, A.: The Rapid Determination in Commercial Products of a Viscous or Semisolid Consistency. Journ. of Ind. and Eng. Chem., i, 1909, p. $25^{2}$. 


\section{$2 \mathrm{BHL}$ Biodiversity Heritage Library}

Miller, Edwin C . 1910. "A physiological study of the germination of Helianthus annuus." Annals of botany 24, 693-726.

https://doi.org/10.1093/oxfordjournals.aob.a089300.

View This Item Online: https://www.biodiversitylibrary.org/item/262605

DOI: https://doi.org/10.1093/oxfordjournals.aob.a089300

Permalink: https://www.biodiversitylibrary.org/partpdf/319808

\section{Holding Institution}

New York Botanical Garden, LuEsther T. Mertz Library

\section{Sponsored by}

BHL-SIL-FEDLINK

\section{Copyright \& Reuse}

Copyright Status: Public domain. The BHL considers that this work is no longer under copyright protection.

This document was created from content at the Biodiversity Heritage Library, the world's largest open access digital library for biodiversity literature and archives. Visit BHL at https://www.biodiversitylibrary.org. 